
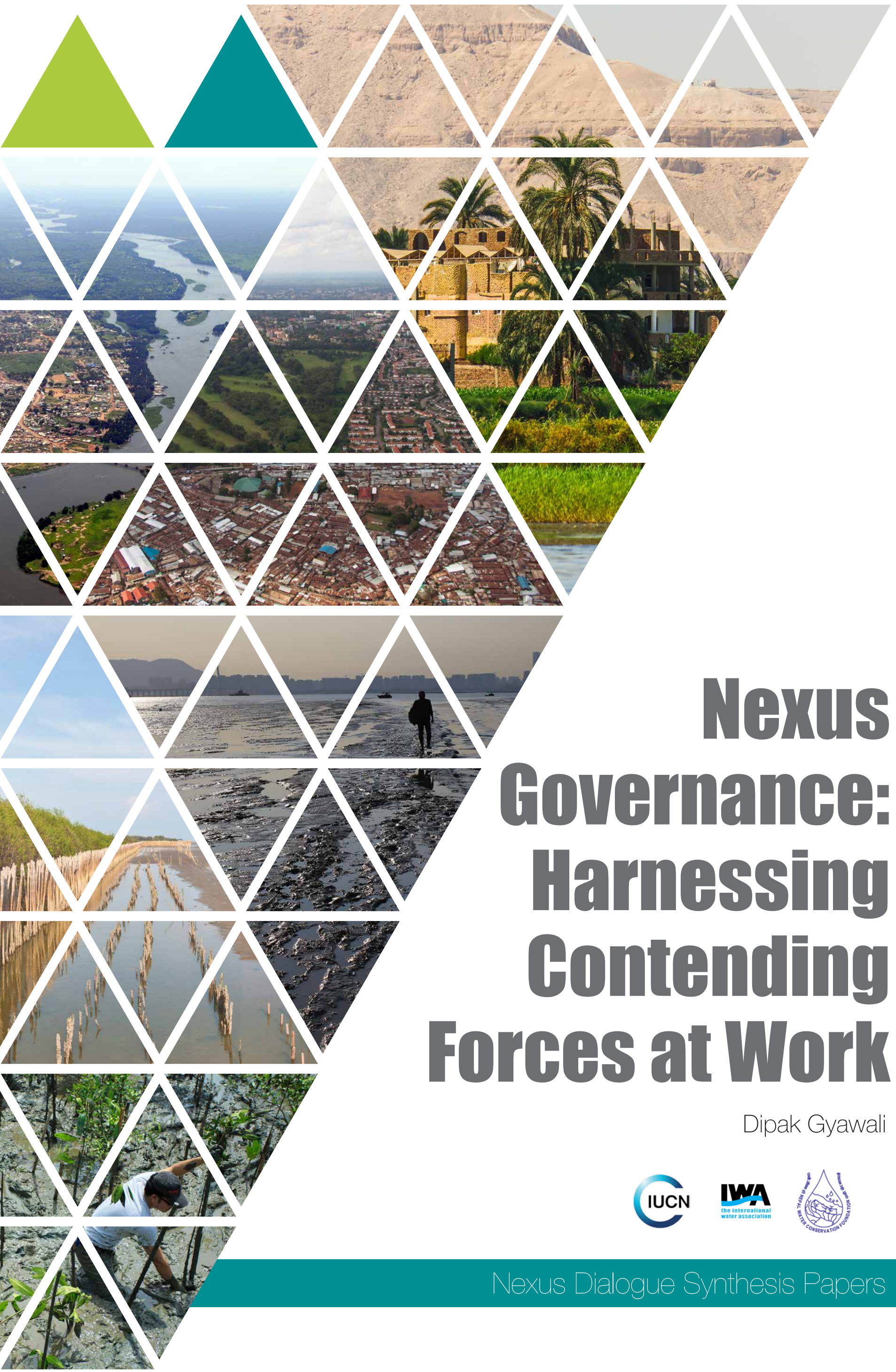
The designation of geographical entities in this book, and the presentation of the material, do not imply the expression of any opinion whatsoever on the part of IUCN concerning the legal status of any country, territory, or area, or of its authorities, or concerning the delimitation of its frontiers or boundaries.

The views expressed in this publication do not necessarily reflect those of IUCN.

This publication has been made possible in part by funding from the US Department of State.

Published by: IUCN, Gland, Switzerland

Copyright: @ 2015 International Union for Conservation of Nature and Natural Resources

Reproduction of this publication for educational or other non-commercial purposes is authorized without prior written permission from the copyright holder provided the source is fully acknowledged.

Reproduction of this publication for resale or other commercial purposes is prohibited without prior written permission of the copyright holder.

Citation: $\quad$ Gyawali, D. (2015) Nexus Governance: Harnessing Contending Forces at Work, Nexus Dialogue Synthesis Papers. Gland, Switzerland: IUCN

DOI: $\quad$ 10.2305/IUCN.CH.2015.NEX.5.en

ISBN: $\quad 978-2-8317-1738-8$

Front Cover From bottom: @ Sura Nualpradid / Shutterstock; Chotewang / Shutterstock; photos: Lewis Tse Pui Lung / Shutterstock; Frontpage / Shutterstock; Alex Pix / Shutterstock; Zhukov Oleg / Shutterstock

Back cover From bottom: @ Bzzuspajk/Shutterstock; Dominique de La Croix / Shutterstock; photos: Oliver Hoffmann / Shutterstock; Esinel / Shutterstock; Manamana / Shutterstock; Gail Palethorpe / Shutterstock

Layout by: $\quad$ UNITgraphics.com

Available from: IUCN (International Union for Conservation of Nature) Global Water Programme

Rue Mauverney 28

1196 Gland

Switzerland

Tel +41229990000

Fax +41229990002

www.iucn.org/publications

Disclaimer: "Working Papers contain preliminary research, analysis, findings, and recommendations. They are circulated to stimulate timely discussion and critical feedback and to influence ongoing debate on emerging issues. Most working papers are eventually published in another form and their content may be revised."

\$ refers to USD 


\section{The Nexus Dialogue on Water Infrastructure Solutions}

Since 2012, the International Union for Conservation of Nature (IUCN) and the International Water Association (IWA) have collaborated on a joint initiative to address competing demands on water resources across the water, energy and food sectors. The objective has been to identify how multisectoral solutions are, or could be provided through infrastructure and other means, including new technologies and investments in ecosystem services. The Dialogue grew out of the Bonn Nexus Conference' in November 2011. One of the objectives in Bonn focused on launching concrete initiatives to address the water, energy and food security nexus in a coherent and sustainable way. The conference highlighted the renewed interest to invest in water infrastructure in different parts of the world because of valid concerns for water storage, water supply and flood protection, as well as food security, population growth, and the need to adapt to climate change impacts.

The Nexus Dialogue 2 successfully organized a series of regional "Anchor" workshops in Africa, Latin America, Asia (with UNESCAP), and for the Amu Darya River Basin in Central Asia (with the EastWest Institute). Learning from these workshops culminated in the Nexus Symposium held in Beijing in November 2014, in partnership with the Global Water Partnership (China).

The Dialogue has focused on water, energy and food to ensure focussed cross-sectoral discussion. The aim was also to prevent creating new silos around issues such as ecology, carbon, soil, climate, etc. Sectors do not operate in these silos; they operate through public sector profiles that are loosely structured on water, energy and food production as staples of societal needs and economic development. The purpose of the Dialogue was to identify consensus on sustainable and resilient water management for water, energy and food security.

The nexus is not a one-way discussion. Rather, it challenges beliefs within the tribal nature of disciplinary silos. The nexus as a construct challenges the application of knowledge, and it highlights the need for greater integration on core elements such as data collection, sharing, and interpretation. Through dialogue, opportunities can be created to bring together people with a variety of experiences from across sectors, to brainstorm, and exchange knowledge, with the ultimate aim to move to developing and implementing practical actions.

There are many ways to not agree about the nexus. What becomes clear is that there is a competitive advantage for all institutions, public, private, etc., to better understand the cause and effect relationships they are involved in through both implementation of their mandates, and policy actions and reform. Through better identification of risks, sharing the risks, and optimising the trade-offs that need to be made between sectors, advantages for all sectors can emerge.

1 http://www.water-energy-food.org/en/home.html

2 http://www.waternexussolutions.org/1x8/home.html 
Increasing urbanisation and economic growth provide significant benefits, but also pose a range of challenges especially for water quantity and quality. Water, energy and food security rely on water infrastructure. Recognition of the closely bound interaction between water, energy and food (or the management of land for food, fodder, and fuel production) - the nexus - has led to new demands for water infrastructure and technology solutions.

The aim of the synthesis papers is to bring together sectoral best practice, and to make connections between the multi-sectoral components of the nexus. The papers identify and analyse the main drivers for joint solutions, and the opposing factors that limit working together across sectors. Key factors for an appropriate enabling environment are identified to allow cross-sectoral opportunities to work better and at the most appropriate scale to help bolster existing development approaches. The nexus is only valid as a point of focus if it leads to better development.

The Papers are targeted to a broad audience, but principally four main groups of stakeholders:

Policy Advisors - individuals who advise decision making committees, senior staff and individual decision makers about issues related to policy delivery and reform, investment choices, and activities to deliver national, regional, and global commitments to resource management, environmental protection, and economic development. This includes those in regulatory agencies.

Practitioners - individuals and agencies who are involved in implementing projects and programmes within or across the waterenergy-food sectors. This includes those who are involved in managing and/or designing interventions that tackle competition for water or degradation of ecosystems as a consequence of different sectoral demands for water, for example water for irrigation, hydropower or cooling water, or public water supply. Practitioners include people and agencies in public, private and civil society sectors.
Investors - individuals and agencies that are responsible for conventional water, energy, and food investments, as well as community investors and larger social impact investors. This could include development banks, national government, private finance, philanthropy, urban and city infrastructure investors.

Researchers - individuals who study inter-sectoral linkages through policy research, modelling, system based approaches, infrastructure and engineering, conservation and ecosystems, urban and rural interactions, etc.

The Synthesis Papers are designed to highlight sectoral best practice, and to identify connections between the multi-sectoral components of the nexus. The papers are designed to be standalone documents, but also relate to each other as key thematic areas in the nexus that have been identified from stakeholder discussions during the Dialogue between 2012 and 2015.

All the papers have benefited from lead authors and reviewers from different institutions and disciplines to ensure multi-sectoral and disciplinary perspectives.

- Clean technology for nexus infrastructure solutions - Simon Howarth, Michael Bruce Beck, and Rodrigo Villarroel Walker

- Water stewardship and corporate engagement in the nexus - Stuart Orr and James Dalton

- Influencing pathways of investments for the nexus - Kala Fleming and Alan Kalton

- Natural Infrastructure in the nexus - Suzanne Ozment, Kara DiFrancesco, Todd Gartner

- Nexus Governance: Harnessing Contending Forces at Work - Dipak Gyawali

- Learning from the nexus dialogue - Damian Crilly, Katharine Cross, Mark Smith, James Dalton, Carolina Latorre, Raul Glotzbach, Rebecca Welling, and Dan Wang 


\section{Acknowledgements}

The author is grateful to the following colleagues and peers who provided critical reviews and other valuable contributions to this paper:

- Christopher Scott, Professor of Water Resources Policy, Udall Center for Studies in Public Policy, and School of Geography \& Development, University of Arizona, Tucson, USA.

- Peter Newborne, Research Associate, Water Policy Programme, Overseas Development InstituteODI, UK.

- Marco Verweij, Professor of Political Science, Jacobs University Bremen, Germany.

- Xavier Leflaive, Principal Administrator, Environment Directorate, OECD, France.

- Carl Middleton, MA in International Development Studies (MAIDS) program and Center for Social Development Studies (CSDS), Faculty of Political Science, Chulalongkorn University, Thailand.

- M Bruce Beck, Professor, Department of Civil \& Environmental Engineering, Imperial College, London, UK.

- Professor J. A. [Tony] Allan, King's College London and SOAS London, UK.

- Jeremy Allouche, Research Fellow, Institute of Development Studies and member of the ESRC STEPS Centre, University of Sussex, UK.

- Tira Foran, Research Scientist, CSIRO Land and Water, Canberra, Australia.

- Stephen Biggs, Research Associate, Department of Development Studies, School of African and Asian Studies (SOAS), University of London, UK.

- Christopher Butler, Lecturer, Department of Sociology, University of Minnesota, Morris, USA.

- Christian Bréthaut, Geneva Water Hub - Education \& Knowledge, Institute for environmental sciences, University of Geneva, Switzerland.

- Rob Nieuwenhuis, Senior Consultant, Mott MacDonald, Arnhem, Netherlands.

- Michael Thompson, Senior Research Scholar, Risk Policy and Vulnerability Program, International Institute for Applied Systems Analysis (IIASA), Laxenburg, Austria.

- James Dalton, Coordinator, Global Initiatives, IUCN Water Programme, Gland, Switzerland.

- Rebecca Welling, Project Officer, IUCN Water Programme, Gland, Switzerland.

- Katharine Cross, Programme manager, International Water Association, Bangkok, Thailand.

Plus organisers and participants at the Stockholm International Water Week 2014 Workshop Entwined Predicaments: Limits Facing Water and Energy; SEA-EU-NET II Workshop at AIT, Bangkok, January 2015; and the Fulbright Water-Energy-Food Nexus Workshop Kathmandu, February 2015. 


\section{Contents}

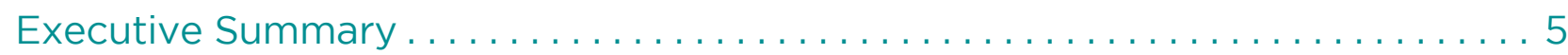

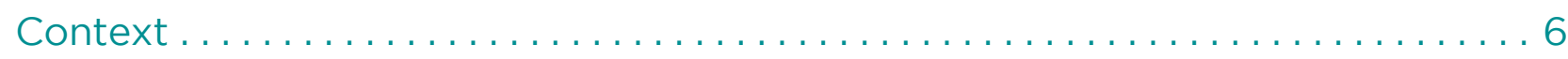

Nexus versus Silos $\ldots \ldots \ldots \ldots \ldots \ldots \ldots \ldots \ldots \ldots \ldots \ldots \ldots$

Case Studies. .............................

The Kulekhani Reservoir, Nepal . . . . . . . . . . . . . . . . . 8

The Melamchi Transbasin Water Supply, Nepal . . . . . . . . . . . . . . . . . . 12

Examples of De-Nexusing from India and Thailand . . . . . . . . . 15

Integrating 'Process versus Decree' . . . . . . . . . . . .

'Integrated Social and Behavioural Science'. . . . . . . . . . . . . . . . . . . 19

Whither Nexus Governance? . . . . . . . . . . . . . . . . . . 24

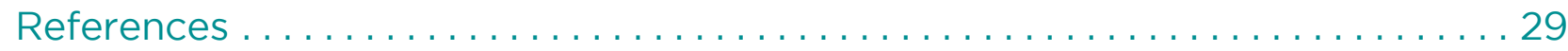


For many rural farmers, fishers, and community groups, food, water and energy resources are not considered as separate pillars but are part of the system they live and work in and need to be managed accordingly. Therefore, at the local level, the nexus is a practical everyday reality. However, the conceptual separation and consequent management of these resources is what has happened in the world of experts and government bureaucracies.

Using case studies from Nepal, India and Thailand, this paper explores challenges and governance options that can accept social and physical uncertainties and build synergy across the water, energy, and food sectors. Examples from Nepal, focusing on its only large storage reservoir, the Kulekhani, and its biggest inter-basin water transfer project, the Melamchi, are used to illustrate what unintended consequences a silo approach, either by design or default, can have.

Given the historical lack of success of previous efforts at 'integrated management' there is a need to ask how the water, energy, food policy terrain can be expanded to allow for a wider range of institutional voices at different hierarchies to be included. Often they may define the nexus 'problem' very differently. Nexus thinking can be encouraged either by leadership or shocks to the 'system', both of which can be taken advantage of if they arise. In normal mundane times, opening silo-based approaches can be encouraged by a process of constructive engagement between plural voices of different styles of organizing - hierarchism, individualism and egalitarianism - and at levels from the village commons to the national and regional levels.

This has the advantage of structurally bringing different concerned parties into a horizontal discussions rather than one that is normally vertical, hierarchical and top-down. Information and joint opportunities can then be easier to identify, allowing silos to be linked, i.e. 'nexused'. Based on the case studies presented in this paper, what remains clear is that dominance, or an unequal balance in favour of hierarchies and against the other two, can lead to the creation of problems for different sectors and often missed opportunities across sectors.

Binding common objectives across institutions and down through sectors through appropriate indicators for example can help to send clear messages to donors and investors regarding clear multi-objective investments that should make them question their own silos. It is compromises with sectors and silos that will lead to better outcomes across sectors. 


\title{
Nexus Governance: Harnessing Contending Forces at Work
}

\section{Reflecting on the tug-of-war between 'organizing-disorganizing' proclivities}

\author{
Dipak Gyawali1
}

\section{Context}

The realm of the natural resources 'commons' such as water, air, forests and land or even minerals span an ownership spectrum with shades of grey, from private to public, community to market or formal to informal and much in between. Their efficient and equitable management has long been a matter of concern at levels of both political philosophy and actual practice. With the rise of the environmental movement in the 1960s and the '70s as well as its associated justice-seeking social counterpart, the subject has been one of fierce debate; and the current 'nexus' debates stem from this pedigree, albeit a bit wiser and more informed as every succeeding generation inevitably is. It also, therefore, carries within it all the unresolved debates of the past, the most of important of which has been that of complexity and complex interlinkages, physical and social, as well as the challenges of managing such an incipient 'clumsiness' (as described below) within different socio-environmental contexts, together with their histories that have shaped their unique national and international institutions.

This Synthesis Paper, while attempting to generalize across the scope and scale of varied global experiences, is grounded in the knowledge of the South Asian Ganga basin. It takes as its starting point an earlier (but on-going) effort (Allouche, Middleton and Gyawali, 2014, 2015) that reviews the origins of the 'nexus approach' and tries to inject a more dynamic perspective that allows for governance approaches that

\footnotetext{
Pragya (Academician), Nepal Academy of Science and Technology (NAST) and Chair, Nepal Water Conservation Foundation (NWCF)
}

accept social and physical uncertainties while building synergy across the water-energy-food (WEF) sectors. In those exercises, we argue that a new framing of the nexus debate needs to acknowledge the market-technical framing but move much further by addressing head-on the political economy and geopolitics of inequality, manufacturing of scarcity ${ }^{2}$ and their contribution to social instability.

An obvious starting point in re-thinking the nexus is its predecessor, as it were- the entire experience of the Integrated Water Resources Management (IWRM) approach over the last two decades. There is an even older pedigree as well, namely the efforts in the 1970s at "integrated rural development", which too exhibited the denexused management problems seen in IWRM. Nexus and "integrated management" can therefore also be seen as on-going, unresolved problems of complex development and its governance.

IWRM has been critiqued from many approaches (Allan, 2003; Jeffrey and Greary, 2006; Biswas, 2008; Moench et al, 2003; Gyawali and Dixit, 1999; Molle, 2008, Smith and Jønch Clausen, 2015) and what is common to all is the failure of the IWRM approach to answer two fundamental questions which suggestively remain as 'residues' in the nexus debate as well:

- Who does the integrating? (agency) and

- How? (process)

2 Author's chapter (Construction and Destruction of Scarcity in Development: A Case Built from Water and Power Experiences in Nepal) on how unbridled, vertically integrated monopoly electric utilities end up creating scarcity in order to control and manage it in (Mehta, 2010) 
While IWRM achieved the status of a powerful mantra incanted at various policy levels from the national to the global, it remains unoperationalized or even un-operationalizable at the level of governance where it matters at least in its strict form, according to the very demanding criteria which have been set for IWRM. Even when codified in formal policy documents such as national irrigation or water policies, the official water management agencies have continued with their business-as-usual construction contracts for cement and earth-moving with little thought given to water, farmers or their crops, and even less to the energy for processing, storage and transport (Gyawali, 2013). It has led in activist circles to the cynical conclusion that in reality, IWRM was dressed to please but bereft of genuine integration of the myriad of often complex concerns, due to its purely technically focused 'expert' driven dialogue.

Indeed, what has remained unanswered in Integrated Rural Development Projects or in IWRM were issues such as:

- whose interests should be reflected in the integrating process and how should such a process be governed to ensure that the interests of all concerned (especially those of the poor and the marginalized), are adequately reflected;

- at which levels, in family households and farms or at national and international regimes, are integration easy and effective and through which modalities;

- how should disputes be resolved, topdown using the coercive arm of the state or horizontally with community conflict mediation; or,

- when can some water management issues be addressed in isolation and with highly specialized and expensive expertise (waste disposal from treatment plants ${ }^{3}$ ) while others

3 This is true only if wastewater treatment is seen as highly specialized engineering treatment of urban sewage effluents and returning the treated wastewater (to varying degrees of treatment as required by environmental acts) to the natural water bodies. When such absorptive limits of water bodies are crossed, or when other concerns of good governance elbow in, the return of treated effluents have to be seen as a nexus problem, as the Saxony German case of a treatment plant needing to convince farmers to use its water for agriculture and go into energy production from bio-wastes. See VillamayorTomas et al (2015), and Beck et al (2011) for the need to replace 'waste' with 'nutrient recycling'. (water allocation in conditions of scarcity) cannot, i.e. which issues are more amenable to 'silo' approaches and which issues need integrated treatment and when?

These are some of the governance issues that will also haunt the nexus approach and which the following sections of this paper will try and address.

\section{Nexus versus Silos}

In order to ground the debate on nexus governance, it will be worthwhile to start with some examples (and conceptually telling ones) from Nepal as well as from Thailand and India that shed some light on the opposite forces of 'silo-ization'. ${ }^{4}$ As the nexus debate accelerates, many more such cases will come to light, both of successes and failures, throwing better insights into the governance efforts of managing the entwined predicaments of water, energy and food. The "best practice" approach, especially of IWRM and its toolkits, has also allowed development partners large and small the luxury of not having to engage in hard critique and uncomfortable reflection on institutional and other failures. Learning by doing and then reflecting upon it is how people learn.

A professor at the Asian Institute of Technology in Bangkok has remarked that "to many rural farmers, fishers, and community groups, food, water and energy resources had not been conceptually separated in the first place compared to the fragmentation that has occurred in the world of experts and their disciplinary approach to knowledge" (Middleton et al, 2014). At the level of a rural or urban

4 These examples are drawn from the cases examined in the following background papers: an on-going comparison between the Mekong and the Ganga by the authors of the STEPS Center's Nexus research Allouche, Middleton and Gyawali, (2014), Middleton et al, (2015), Gyawali, D. (2014). Visible and Invisible FoodWater-Energy Nexus: Lessons from Nepali Case Studies. Kathmandu: Nepal Water Conservation Foundation. They were based on interviews with fishing families along the Kulekhani reservoir by the author as well as with farmers in the informal "farmer-managed" irrigation systems in the East Rapti basin below the Kulekhani-3 tailrace and above the township of Heatauda in Makwanpur District of Nepal. The Melamchi example is drawn from several investigative reports (e.g.: http:// nepalitimes.com/news.php?id=8050\#.VQu_fo6Ucb8) as well as the many meetings organized by the Nepal NGO Forum campaigning for a more nexused Melamchi, a short summary of which is provided as Multi-Purpose Melamchi Project, Nepal in HYDRO NEPAL, Issue No. 9, July 2011. 
household, water-energy-food decisions are always 'nexused' for the householder in the sense that household concerns regarding these three necessities combine, and decisions in favour of family well-being cannot ignore one or the other as tradeoffs are made. This happens even when distorting national government policies of subsidy (catering to vote-bank politics, i.e. almost free electricity to farmers or cooking gas to urban dwellers) lead to perverse environmental consequences when seen from a higher level of national or global governance.

It is when decisions are taken at the higher levels of administration at the district/region, nationstate or the level of global development agencies that there is increasing specialization and perplexity regarding the entwined predicament of intermeshed water-energy-food issues and how best to address problems in one without being hit with surprises emanating from the others. There are iconic examples particular to specific countries that need to be examined to understand where and why the nexus fails so that insights and elements of the lessons they point to can be valuable in understanding nexus problems in other climes as well. These need to be reflected upon in trying to understand why WEF nexus, so obviously full of benefits when looked at academically even from different frameworks, is difficult to administer in practice by modern administrators, but can more easily be applied by farming or urban households.

The following sections use case study examples from Nepal, India and Thailand to highlight some of the challenges in development approaches to harness multi-sector, multi-discipline, and multipurpose thinking.

\section{Case Studies}

\section{Case study 1 : The Kulekhani Reservoir, Nepal}

Despite the fact that for almost half a century, Nepal has been touted as a country "rich in hydropower potential", Kulekhani is the only seasonal storage type hydroelectric project in the integrated Nepali power grid and the only large dam Nepal has. Even more ironically, the country suffers periodic cycles of power cuts and power gluts (termed the 'flood-drought syndrome') and has been facing up to fifteen hours of power cuts a day since 2011. Cynics do say: Forget the WEF nexus - the country cannot even properly manage a single sector. Governance failure in one sector should make resource managers more cautious before bringing in additional complexity. They need to first have a better nuanced understanding of the entwined issues as described in this case.

The cascade of Kulekhani Hydroelectric Power Stations is located $30 \mathrm{~km}$ southeast from Kathmandu. Two power stations already operational within this cascade complex are the $60 \mathrm{MW}$ Kulekhani No 1 (KL-1) at the upper end of the cascade that has a high dam of $114 \mathrm{~m}$ and a reservoir. It stores a gross volume of 85 million cubic meters (MCM) and a live volume of $73 \mathrm{MCM}$ of monsoon flow in the river which is not snow-fed. A lower $32 \mathrm{MW}$ Kulekhani No 2 (KL-2) uses the tailrace waters of KL-1 and a $14 \mathrm{MW} \mathrm{KL-3}$ is nearing completion further below, despite severe time and cost overruns, which will use the tailrace of KL-2. The Kulekhani No. 1 construction was completed in May 1982 with two turbines of $30 \mathrm{MW}$ each. This was followed by the construction of Kulekhani No. 2 which was completed in November 1986. The Kulekhani cascade is operated by a vertically integrated monopoly public utility, the Nepal Electricity Authority under the Ministry of Energy (previously Water Resources).

$\mathrm{KL}-1$ was conceived purely as a peaking hydroelectric plant, and considerations of using the stored water of Kulekhani, either within the reservoir for fisheries or downstream for irrigation and drinking water, were never part of the official project design by the government agencies nor proposed as such by the World Bank as well as the Japanese aid agency JICA bankrolling it. There have been writings by activists and academics in the local media suggesting that the stored water can serve a range of uses, i.e. nexus activities. They range from: using the higher water level in the reservoir to supply gravity flow drinking water to the chronically water scarce capital city of Kathmandu located at a lower altitude; promoting tourism and fisheries in the lake; increasing dry season irrigation in the downstream reaches from the stored releases; providing more municipal water supply to the town of Hetauda below KL-3; and enhancing environmental flows to the national wildlife parks 
in the downstream reaches. While obviously beneficial, they have fallen on deaf official ears of the utility, the concerned ministry as well as the National Planning Commission chaired by the prime minister, that refuse to see the reservoir as anything other than a peaking pond for hydroelectric generation.

This silo deafness has, however, not prevented other social solidarities (informal ${ }^{5}$ markets as well as social and environmental groups) from exploiting the created resources or advocating alternative uses. This disjuncture between the official and the unofficial, the formal versus the informal and the national versus the local is what the Kulekhani case highlights; it is a case of lack of nexus in governance, while practice on the ground by local people does acknowledge the possibility of multiple uses of the resource. Unlike other proposed storage dams in Nepal, Kulekhani is on a small fourth order tributary of the Ganges without an international transboundary element in its debates, which is purely focused on domestic Nepali issues and which should, in principle, have been easier to resolve.

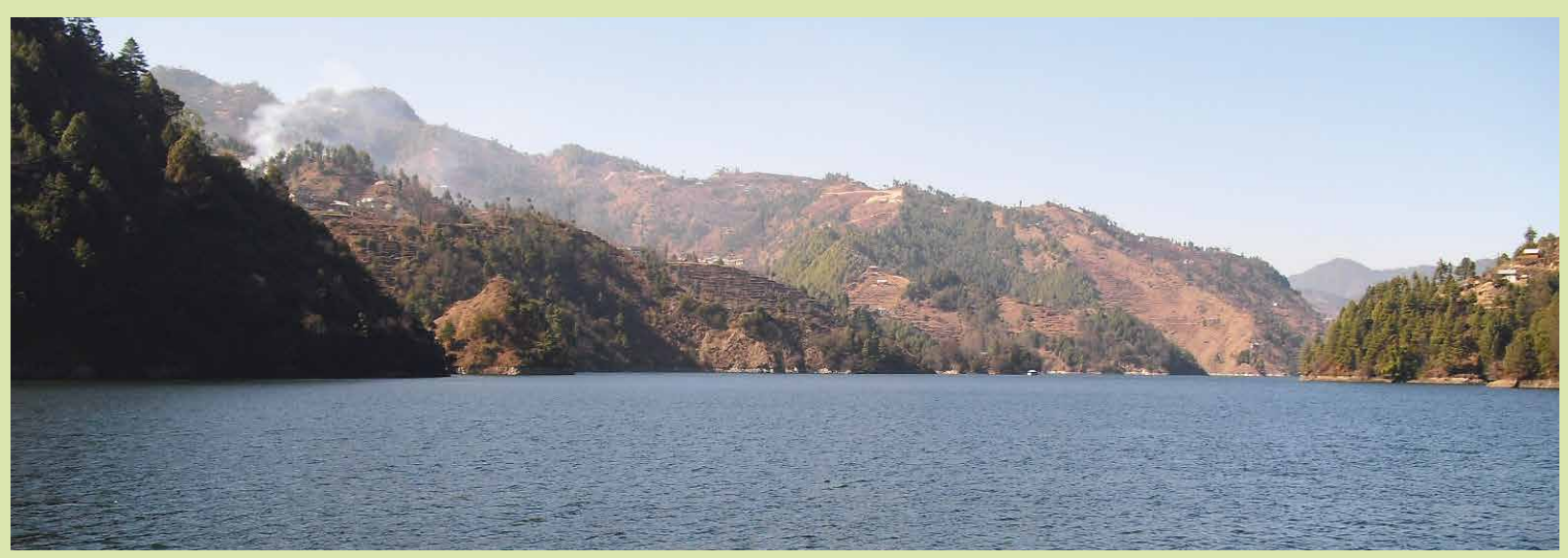

(c)Dipak Gyawali

When the project was seriously considered for implementation in the early 1970s, the country did not have an argumentative democracy but was ruled by a party-less Panchayat system of 'guided democracy' and there was virtually no opposition of any kind. The relatively small number of people who were to be displaced by the dam received the official compensation and told to move away. There is a poor record of who exactly was displaced and what they received. In interviews with people in the catchment area, it appears compensation money did not find productive investment possibilities and some of those displaced moved to downstream townships such as Hetauda in search of livelihood options.

The real conflicts with the project began long after its completion with the restoration of multiparty democracy and the ability of the populace to voice public grievances. In July 1993, a major disaster struck the project when an intense cloudburst, lasting 30 hours with intensity of up to $60 \mathrm{~mm} / \mathrm{hr}$, dumped as much as $540 \mathrm{~mm}$ of rain in just 24 hours. Rainfall and landslides in the catchment area practically filled up KL-1's entire dead storage volume that was planned to last 100 years. Subsequent bathymetric surveys indicated that actual sedimentation into the Kulekhani reservoir was orders of magnitude higher than designed for. Bridges and sections of the national highways were washed away as were 67 small and large irrigation projects in mid-hill central Nepal; and some two thousand people lost their lives.

The torrential rains had dislodged hill slopes and washed away the penstock of KL-1 shutting down its operation completely (equivalent to $40 \%$ of the total grid power), requiring serious (and expensive) counter measure constructions. In particular, an innovative but costly "sloping intake" was constructed that allows the intake point of the headrace tunnel to be moved up as the lower part of the reservoir fills up with sediment. It is during this phase of rehabilitation/reconstruction that disagreements and conflicts came to the fore highlighting the interactions between sectors (the nexus) and the impact on the reservoir.

5 Informal economy, although it dominates in Southern countries (and is present in significant size even in the industrialized North), is something that falls within the blind spot of development thinking. This paper proposes that they should be brought to policy salience, and can be so brought, only if the local level is given more say via a nexus approach conducive to it. These arguments are also made in Gyawali (1996) as well as Gyawali and Dixit (1999). 
The people who lived within the catchment around the reservoir area but who lost their lands at the valley bottom when the river was dammed had begun cage fish farming with encouragement by activists and some Japanese volunteers. There were no official agreements for this with the national utility that managed the dam; and the utility officials were not bothered either since it did not affect their power generation. When the 1993 disaster struck and the sloping intake had to be constructed to make the plant functional again, the utility resorted to sudden and quick dewatering of the reservoir during construction, killing all the fish that the villagers had been farming. A massive conflict issued at the local level.

The initial official utility position was that it was their pond and they could do what they liked, "even pour poison in the reservoir", that the people fishing there had no official right to do so. Given that multiparty democracy had just been restored in Nepal, it was difficult for the political parties to go along with the official hydrocracy (the expertise-dominated utility and ministry bureaucracies), and a compromise of sorts was worked out. The fisher folks would be paid a one-time compensation of almost a million rupees and they would be free to continue with their fish farming in an informal way. However, if anything untoward happened due to reservoir operations by the utility, they could not claim any compensation in the future. This confirmed energy (hydropower) as the dominant use (i.e. an un-nexused reservoir) and other reservoir benefits never figured in the official equations.

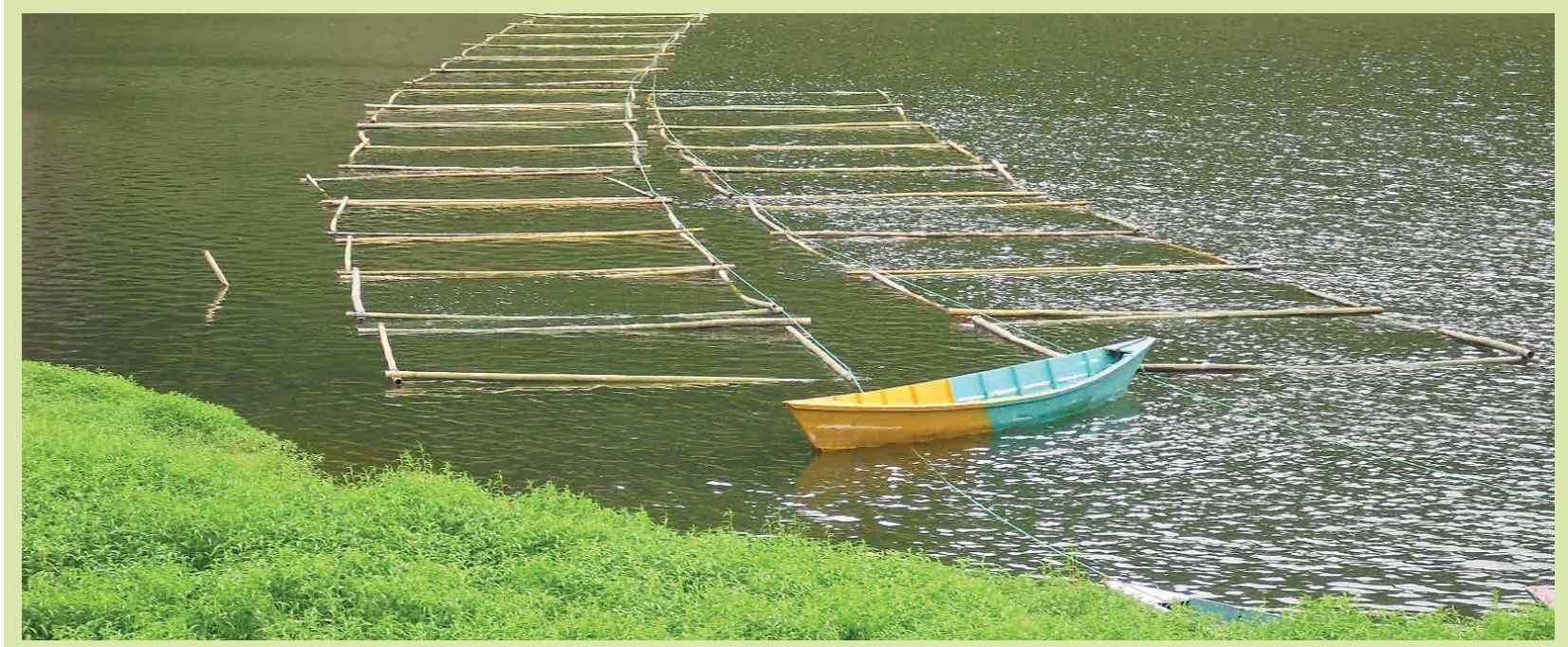

(c)Dipak Gyawali

The fish farming continues de-nexused in the informal economy engaging some 307 families around the reservoir area. They are now self-organizing into a self-help cooperative with members having fixed shares so as to prevent overfishing through self-regulation. There is virtually no national government regulation over this economic activity, and local government elections have not been held in Nepal now for some eighteen years for local village or district governments to step in with politically acceptable regulatory measures. Cage fishing has now declined in favour of capture fishing which constitutes about 80 percent with the former accounting to only about $20 \%$ of the catch. In 2013, the families sold some 52 thousand kilograms (kg) of fish. The as-yet unregistered cooperative also allows tourists to do some angling for a fee of Rs 500 provided they catch less than $5 \mathrm{~kg}$ (if more, they have to buy it back from the cooperative).

The catch amount varies. It is about 100-150 kg per day in the winter, 200-300 kg during the monsoon and up to $500 \mathrm{~kg}$ in the post monsoon months. Nepal government rules now stipulate that some 12 (very local) +38 (districts in the region) $=50$ percent of the government's royalty from hydropower plants have to go to local village and district governments respectively ${ }^{6}$. The fisher folks are demanding that some of that money come to them too and that they receive help in running motorboat services (replacing paddled canoes) for transport between villages on opposite sides of the lake. All this is being done quite openly and mostly in the informal sector with no official "nexus" planning with the Nepal Electricity Authority.

6 It is a complex as yet not streamlined but contested set of formulas that divide the fifty percent into very local impact area, village as well as district and regional administrative units they fall under. 
The other set of "de-nexused" activities are downstream of the dam. Interviews with two sets of beneficiaries from the valuable stored waters coming out of the tailrace of the Kulekhani system - monsoon flows that are now regulated and released in the dry season when river flows are low - were conducted: the informal farmermanaged irrigation systems along the Rapti river where the tailrace empties into, as well as the Hetauda municipality. There are several what are called traditional (and mostly in the informal sector) farmer-managed irrigation systems (FMIS) in the vicinity that have used the waters of the East Rapti for some time and now use the extra releases from Kulekhani HEP operations in the dry season that was not there when there was no reservoir and allied power generation (These additional dry season releases are the exigencies of power plant operation, not considerations of irrigation needs). These irrigation systems range in size from 35 hectares to 150 hectares and use traditional technologies that divert the river waters for irrigation with brushwood dams and simple gravity flow unlined canals. In very dry seasons, diesel and electric pumps are sometimes used to pump supplemental water from the river itself.

Exact quantification is near impossible at this stage; but it is obvious from interviews with farmers that the released waters from the tailrace of Kulekhani cascade has increased the flow in the river, especially in the very dry seasons of February to May, allowing for more irrigation than would have been possible without the

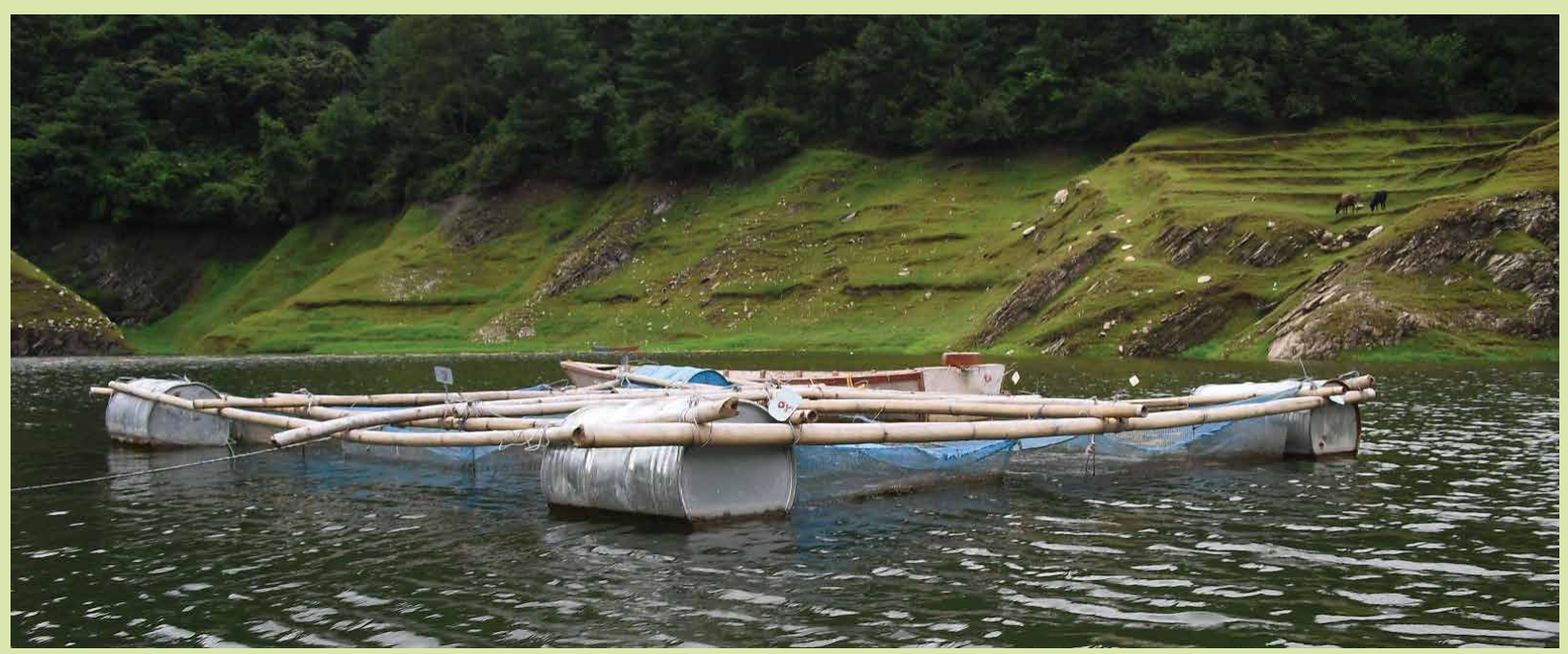

(c) Dipak Gyawali

upstream reservoir. The official irrigation department of the government is only now beginning to look into this phenomenon, the beginning of benefits for agriculture from operation of water infrastructure for energy (the nexus) that happened (when the interview was conducted) because a new Department of Irrigation official (appointed to its Hetauda office) happened to be a local resident. This fortuitous case bolsters the argument that a more representative political process at the local level is more prone to a nexus approach than one where it is absent or where the central hydrocracy is dominant.

The other "de-nexused" player is the industrial township of Hetauda Municipality and its water supply system on the East Rapti river downstream of the KL-3 tailrace. This town is experiencing growing water shortage and is eyeing the stored waters released by the Kulekhani cascade's tailrace to augment its supplies. Initially, this matter was not even imagined as an option while the town's water supply was operated by the national level Water Supply and Sewerage Corporation managed out of the capital Kathmandu (which manages the water and sewerage systems for all major towns of Nepal). However, due to increased public pressure recently, the water supply system has been decentralized to a local board of Hetauda residents. With this devolution of power to a lower unit of government, suddenly a claim for water which invites nexus thinking has arrived and consideration of augmenting the town's water supply from the KL-3 tailrace is very much on the table.

There are, however, many negotiations ahead between these four very different players of electricity, irrigation, fisheries and domestic/industrial water supply - in the past, there has been a clear case of development of water resources for a specific use that doesn't consider the impact on other sectors (de-nexused) which is 
now subject to a process of co-operation across the different users (re-nexusing). Thus, while a formally denexused approach exists at the official national Nepal government or international aid agency levels for foodwater-energy in the largest and only big reservoir in Nepal, a re-nexusing is happening but only with local and informal initiatives under the pressures brought about by greater democratic devolution of power. It is not clear how this dynamic will evolve: will an aggressive municipality eyeing the tailrace waters for domestic and industrial use be considerate of irrigation needs of upstream farmer-managed irrigation systems?; will the fisher folks in the reservoir vicinity be able to put enough pressure on hydropower officials to operate the reservoir with considerations for fish breeding?; and will the national government supra agencies not have to step in finally at some point to mediate between conflicting local interests with the nexus approach in mind?

\section{Case study 2: The Melamchi Transbasin Water Supply, Nepal}

Kathmandu Valley, housing Nepal's capital, has been facing chronic water shortages for many years. Given that the Valley receives about $1200 \mathrm{~mm}$ of annual precipitation on average (eighty percent of it in the four monsoon months of June to September and the rest from winter westerlies), it stands to reason that natural shortage could not be that much of a cause of the scarcity. "Unmetered consumption" is rife as are technical losses from leaky pipes and tanks. Numerous studies from the 1980s by different donor agencies have placed leakage and theft of water in the overall official utility distribution system of Kathmandu valley at as high as seventy percent. ${ }^{7}$ However, water scarcity is the essence of the local political narrative; and since the 1970s, the Melamchi transbasin transfer of water to the Valley has been projected as the iconic project of salvation for Kathmandu's water supply.

Diverting water from the upper reaches of the Melamchi river, a tributary of the snow-fed Sun Kosi north of Kathmandu into the valley was identified as a viable measure to remedy the water shortage problem of Kathmandu valley some forty years ago, in the early 1970s. The World Bank picked it up as its flagship project in the 1980s but had to pull out of it in the mid-1990s, primarily because the conditions of the Bank attached to the funding were not politically and administratively palatable to the government and partly because adding more supplies to a system that leaked (or suffered leakage and illegal offtakes) more than half its design capacity, without first plugging the leaks, was hardly justifiable.

Not that there were no efforts to address those issues: there were twinning arrangements with British utilities to help the Nepali utility learn to do things better, expensive leak detection consultancies, etc. But the core institutional disjuncture - water supply of towns across Nepal managed not by their own municipality but by a central government entity - was never politically addressed by Nepali authorities. The big donors such as the World Bank were also not interested in managing many small, different projects in small towns. They would rather give (and manage) single loans to one big national entity - the Nepal Water Supply Corporation - and hence never seriously addressed (nor really pressured Nepal government to address) this grave contradiction that continues to be a challenge for Nepal's urban water management.

After the World Bank pulled out in the mid-1990s, the Asian Development Bank (ADB) stepped in to promote this project, initially in partnership with the Norwegian aid agency. However, some disagreement occurred among these development partners, the Norwegians being interested in a hydropower component which the ADB and the Nepal government line ministry (of housing and physical planning) were not interested in adding as a complication. It is now an ADB-led venture (with support from Japanese JICA and the OPEC Fund) with only the urban water supply component on its horizon. The principal Nepali line agency for this project is the Department of Water Supply and Sewerage of the Ministry of Housing and Physical Planning, whose mandate is water supply and within which there is strong resistance to adding electricity or any other component that would attract the quest for a project share by other line agencies. Thus the stage was set for this very large

7 Between February to April 1987, the author served as a member of the 'Pokhrel Commission' (constituted by the Prime Minister of Nepal and chaired by a member of the then Nepal parliament and a former chief engineer Mr Birendra Keshari Pokhrel), formed to investigate why twelve years of World Bank efforts to ameliorate water woes in twelve cities of Nepal including the three in Kathmandu valley, yielded little by way of progress. Much of what is described in this short summary regarding the water supply utility and the then nascent Melamchi project (as well as competing donor interests) is also fed by experience and insights gleaned during that exercise. 


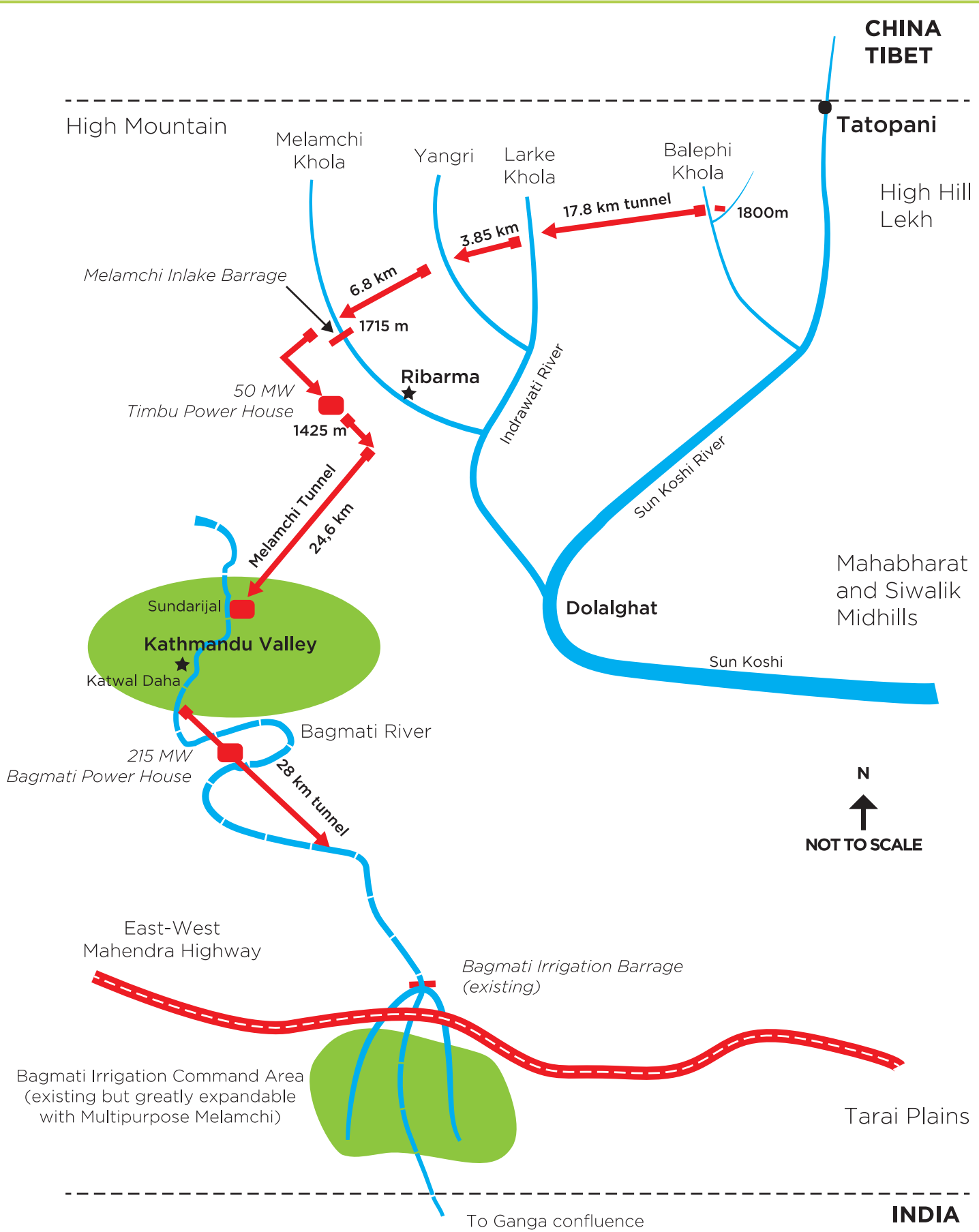

(adapted from Jantzen, etal (2008) and Hydro Nepal, Issue No. 9, July 2011)

project for Nepal (equivalent of USD 235m without accounting for cost and time overruns as the years - and contractor variation billings - roll by $)^{8}$ becoming a single-purpose, water supply project for Kathmandu.

According to projections made in early conceptualization of this project by Nepal Water Supply Corporation, Kathmandu valley would have a demand of 310 million liters per day (MLPD) of water in 2010 increasing thereafter by about ten percent per annum 9 . However, the Melamchi project will be adding only about 170 MLPD during the dry season to the existing volume of supply which is 90 MLPD.

8 http://www.melamchiwater.org/home/project-finance.php

9 They do not really account for the jump in Kathmandu's population by ten times from three hundred thousand in the late 1980s to about 3 million today, mostly due to the decade long Maoist insurgency in the hinterlands that led to people who could to migrate to Kathmandu in search of security. 
This volume is insufficient in view of the projected demand that requires another addition of 100 MLPD to what Melamchi plans to deliver. Furthermore, taking the officially acknowledged leakage level of 40 percent into consideration (other studies suggest 70 percent), the actual amount of water available in Kathmandu valley will be 156 MLPD even after augmenting it with the water diverted from Melamchi. Therefore, even after the completion of the Melamchi project as it is designed, the problem of water scarcity in Kathmandu valley will still persist. As the ADB forced a covenant in the loan documents requiring massive escalation of tariff, the valley population will face escalated prices without resolving the bulk water shortage problem ${ }^{10}$. Although economic orthodoxy maintains that increasing tariff can direct utilities to invest in leakage reduction, it has not happened because commensurate institutional reforms have not been done; and consumers have shifted to other private and informal suppliers, further reducing the utility's revenues.

The Melamchi project involves the construction of a tunnel located at an altitude of 1700 meters on the upper reaches of the Melamchi river to bring water down to Sundarijal in Kathmandu valley (1400 meters) thereby creating a head of 300 meters so that about $25 \mathrm{MW}$ power could be generated as per the original blueprint when the Norwegians were still involved with this project. But the idea of generating hydropower was later abandoned claiming that it was not feasible. It is true that having to dig a 27 -kilometre long tunnel just to generate about $25 \mathrm{MW}$ of electricity sounds too expensive even at a cursory glance. But the fact was filtered out by those pushing for a single silo water supply project that the tunnel has to be constructed anyway to divert water into the Kathmandu valley. Therefore, if one were to generate power from the same water, the incremental cost of the tunnel would be low for the power generation component. However, if it was treated as an overall multipurpose project, the tunnel cost could be borne by one or the other sector or shared by them through some governance equation, reducing cost to both. This aspect was not considered by the ADB and Nepal's water supply department in deciding to abandon the hydropower component.

Interestingly, in contrast to the image of NGOs as obstructionist and only opposed to dams, Nepali NGOs, like most of their Southern counterparts do not say "No Dams!" but instead argue "No Bad Dams!" In the case of Melamchi, they argue that if a river is to be sacrificed for the good of human society, sacrifice it well to maximum benefit. Instead of the current "de-nexused" single purpose design that only produces expensive drinking water (and insufficient amounts at that!) and ignores the potential for hydropower, they want the project designed for a "Bigger Melamchi, Multipurpose Melamchi!". They want a few other upstream tributaries of Melamchi such as the Yangri, Larke and Balephi also diverted to the Melamchi tunnel which should be increased in diameter from the currently designed 3.7 meters to five meters at only incremental costs. This will bring 1120 MLPD of water to the valley in the dry season, of which it is estimated that only 20 percent will be lost in consumption and evaporation while 80 percent can be recovered with proper sewerage treatment for a healthy and clean Bagmati river.

Unlike the current official project, this "Bigger Melamchi, Multipurpose Melamchi!" approach of the NGOs is a more nexused one that would simultaneously provide the following additional benefits, not just to Kathmandu valley but the country as a whole. The additional diversions from the Melamchi tributaries would not only provide some $50 \mathrm{MW}$ of hydroelectricity but also triple the dry season flow from six to thirteen cubic meters per second, meeting all possible future demand for drinking water in the valley. Below the Chobhar gorge at the southern tail end of Kathmandu valley, the head difference between it and the Tarai plains of some 900 meters could be used to generate an additional $190 \mathrm{MW}$ of power for the Nepal power grid that currently suffers up to 15 hours of power cuts per day. In addition, the increased dry season flow in the Bagmati river could increase the potential irrigable command area of the lower Bagmati plains in Sarlahi and Rautahat Tarai districts by 30,000 hectares.

This multi-purpose project would - if presented as a 'nexused' approach in an appropriate governance process unlike the current silo one of treating Melamchi as a drinking water project only - provide Kathmandu Valley with more reliable and cheaper drinking water since electricity users across the country would pay for

10 These are only activities in the official public sector. In the private and informal sectors, there has been a parallel boom in tanker as well as bottled water supplies while those who can afford to have been deep drilling for groundwater in what is essentially an unregulated sector. These 'ground realities' have not really entered into official planning which is only Melamchi focused. 
part of the cost of the tunnel. With more flow in the river as well as sewerage treatment plants, the Bagmati river running through the capital city would be cleaner unlike the foul sewer it has currently become. The national grid would get much needed hydroelectricity to ameliorate its severe load-shedding; and the Tarai plains would get dry season irrigation to increase food production. Further downstream river flows may also be affected and therefore would need to be considered in an environmental assessment. Unfortunately, with the current silo approach, only Kathmandu gets expensive and insufficient water; Bagmati river will have insufficient flow and remain a sewer despite provision for some sewerage treatment; Tarai gets no additional irrigation, only Kathmandu's poorly treated effluents; and the country fails to get much needed electricity to ameliorate its crippling load shedding.

This example illustrates that a silo approach - which is a failure of national planning agencies to collaborate between sectors for the greater benefit of all and institutional processes that should be integrating nexus thinking - is not only the challenge of developing counties, but also a challenge for international development agencies, and their multiple advisory services. However, a word of caution is in order: as the motif of levels at which the nexus approach is most effective runs through this paper, the questions: do NGOs represent the forgotten poor downstream of the smaller tributaries that will be diverted to the capital city?; which business interests back their claims? - remain unanswered. The Theory of Plural Rationalities discussed below will try to do so.

\section{Case study 3: Examples of De-Nexusing from India and Thailand}

As mentioned earlier, such de-nexused management pathologies can be found in various other places in the Global South. Rasi Salai Dam, located in the Northeast region of Thailand on the Mun River, is part of the Khong-Chi-Mun Project (KCM) scheme, a large-scale irrigation scheme designed for the relatively arid Isaan (North-East) region by the Thai government. The project was commissioned in 1989, construction began in 1992, and was completed in 1994 as a 17-meter high concrete dam with a large reservoir. Original plans were for the dam to provide irrigation to approximately 5,500 hectares; however, the water from the dam is used on less than 1,600 hectares of land. The dam was originally estimated to cost 140 million Baht, but actual costs were far over budget costing 871 million Baht (nearly six times the planned amount).

Many controversies have surrounded the Rasi Salai dam. The project's Environmental Impact Assessment (EIA) was inadequate. The inundated area was previously an area abundant with rich soils for rice cultivation and wetland forest that provided villagers with other livelihood opportunities. Affected people are still lacking fair compensation, with approximately half of the affected villagers who have either received insufficient or no compensation. Collateral losses, including the loss of approximately 15 fish species and river and wetland diversity, have never been officially assessed or acknowledged. Over the course of the project, villagers were repeatedly excluded from the decision-making process and access to information was denied, especially in the final stages of construction. Furthermore, the Rasi Salai Reservoir sits on top of a large underground rock salt deposit. This has resulted in water seeping down to the underground salt domes and drawing salt back up into the reservoir thus increasing salinity and decreasing the productivity of irrigation as crops are exposed to salt water.

Early interventions (in the 1930s to the 1950s) emphasized small-scale tank irrigation and river diversion projects in this region of Thailand. However, with the backing of the US Bureau of Reclamation and since the 1970s also the then newly created Department for Energy Development and Promotion, the ambitions of the hydrocracies have increased and accelerated successive waves of large- and medium-scale dam and diversion schemes. These developmentalist visions of large irrigation and independently large hydropower schemes have often been heavily contested between state and civil society including villagers, social activists, NGOs and academics. These contestations have been on the grounds of their environmental and social costs, and with divergent visions of the region's development who argue that a lack of post-facto evaluation hides the extent of irrigation development failures in Northeast Thailand. This has happened despite IWRM having become the accepted mantra of Thai water agencies; and similar stories abound in other parts of the Mekong and the Ganga. 
In a comprehensive look at water, energy and food issues in India, Kumar et al (2014) examine the intertwined nature of these three sectors in much of India that is essentially a semi-arid region with poorly endowed energy resources and heavy population pressure on its food-producing land resources. Each of these sectors is also plagued by the "security approach" that sees shortages and scarcity as threats to national (and very infrequently as human) well-being. There is also the excessive "populism" in policy making wherein a dominant alliance of politicians-bureaucrats-academics is pushing for short, quick-fix solutions to the long-term detriment of the economy of each of these sectors. Absence or lack of appreciation of how these sectors are intertwined and impact each other, together with issues of lack of rural wage labour, as well as underpricing (subsidised) of electricity for groundwater pumping, socially insensitive promotion of hydropower construction and cartel/monopoly ownership of groundwater wells is contributing to growing insecurities in each of the sectors and across the sectors.

\section{Integrating 'Process versus Decree'}

What these and other cases demonstrate is that the reasons why IWRM did not succeed in getting traction on the ground are still alive and strong against the nexus approach. To continue the Kulekhani and Melamchi stories from Nepal described above, the country had a Water Resources Ministry that was responsible for hydropower (Nepal's official national grid is mostly hydroelectric), irrigation, flood control and drinking water under its jurisdiction ${ }^{11}$. The last was hived off to the 'housing ministry' in the late 1980s. In 2010, the Water Resources Ministry (MoWR) was split off into a Ministry of Energy and another Ministry of Irrigation.

Although the single MoWR did not have a stellar track record of nexus thinking, the split further silo-ized irrigation from electricity, and its immediate impact was seen in Nepal-India negotiations on water resources development talks, where comprehensive views and inter-sectoral trade-offs between electricity, irrigation, navigation, flood control and fisheries became even less probable in discussions to develop common projects on Nepali tributaries of the Ganga river. This 'dis-integration' happened despite the fact that the country's official water policy had enshrined the IWRM principle within it, and despite the fact that the majority of the senior bureaucracy was opposed to splitting MoWR (although a small minority that ultimately prevailed wanted to carve out their fiefdoms).

Moreover, Nepal also has a Water and Energy Commission (WECS) since the late 1970s, which

11 Author was Nepal's Water Resources Minister in 2002/03 (and ex-officio the Chair of the Water and Energy Commission) and thus is here expressing his experienced views that are also fed by informal political discussions. Some of that experience is recounted in the special issue of Water Alternatives on Voices of Water Professionals (Gyawali, 2013). has, as members, secretaries of some twelve major ministries such as water, power, petroleum supplies, agriculture, forests, finance, foreign affairs etc. In principle, this institutionally nexused body could serve as the point of nexus thinking and policy tradeoffs between sectors handled by different ministries. In practice, except in the 1980s, this body has not been fully used effectively. Major decisions on large water resources treaties (i.e. the 1996 Mahakali Treaty with India) or projects (Arun-3 led by the World Bank from which the Bank pulled out after protests in 1995 or the Melamchi transbasin water supply project) were either never taken to WECS for advice or if taken, and the advice was unfavourable, were ignored.

While decisions on the three WEF sectors may be nexused at the level of the household, the process of silo-fication gains prominence and strength as you move to higher levels of governance. Similar to university departments where 'interdisciplinary studies' often receive lip-service but actual academic promotion depends very much on disciplinary contributions, rewards in a silo structure is for promoting silo interests and 'empire building' for the concerned silo, not in handling problems of other departments. Nepal's MoWR had two departments of electricity and irrigation as well as one parastatal utility, the Nepal Electricity Corporation till the mid1980s when, under World Bank pressure, the Electricity Department and the Electricity Corporation were merged to create one Nepal Electricity Authority. However, in the late 1990s, a Department of Electricity Development was again revived and a flood control Department of Water Induced Disaster Prevention was hived out of the Irrigation Department, even as the supposedly integrating Water and Energy Commission continued to languish in near limbo. Empire building of silos continues as a powerful institutional motif. 
At the beginning of the paper we asked why the IWRM approach has not been fully successful in being operationalized (it did not adequately answer both 'agency' and 'process' questions and remained fixated with an over-procedural approach). That conundrum needs revisiting with respect to the nexus approach if the latter is to escape a similar fate and result in something more substantive and meaningful. Although having a conceptual pedigree that extends back to the environmental movement, the idea of the nexus gained traction with the entwined financial, food and energy crises of 2007-2008. Given the sense of general dissatisfaction with, if not anger at, the failure of previous official national and international development theologies such as IWRM or the Millennium Development Goals (MDGs) to foresee, let alone forestall, such unpleasant eventualities, a search is on for a new development model that is more sustainable, more constructive and less prone to unpleasant surprises. Towards this end of rethinking development, the nexus approach currently presents a 'theory-in-making' and hence has within it the potential to move away from 'mal'-development to 'belle'-development as the Melamchi example above points to. It may even contribute positively to the Sustainable Development Goals (SDGs).

The Third UN World Water Assessment Report (WWAP, 2009) makes the central argument that decisions affecting water happen not only 'within the water box' but also 'outside the water box', with the latter possibly having a bigger impact on the sector than that by the managers of the former. The broad 'outside the water box' arena consists of political, civic as well as business and economic actors using water as an input supply to its production or consumption needs and not being too concerned with its intricacies except when a disruption to supply occurs. The decisions from 'within the water box' reach the 'outside' managers in the form of demand response options, which forces them to make political and operational decisions within their realms, with choices ranging from conservation to search for new supplies, often with only the price as signal from the water supplier agency or utility managers to guide them.

The decisions of these external 'outside the water box' actors, however, have significant impact on the broader and more deep- rooted drivers of change such as economic, demographic, technological, environmental factors etc. For example, decisions by the finance or education ministries, made without any thought of water or any nexus implications, could have immense ramifications for the water sector. In Nepal, decisions by the tourism sector to open hill-top resorts to enjoy the Himalayan panorama - heights that by their very nature have most of the precipitation run off downwards - have stressed spring sources nearby that subsistence agriculture has depended upon for its very existence, creating a push factor for outmigration of farming communities (ICIMOD, 2015).

These 'outside the water box' decisions have difficult-to-predict consequences for the water sector, especially when they come entwined with predicaments of mutual limits. Moghul emperor Akbar built his dream city of Fatehpur Sikri between Agra and Delhi in 1569; but it had to be abandoned fifteen years later after it reached the limits of water scarcity. Modern India has built cement-and-glass cities like Gurgaon next to Delhi and Gandhinagar in Gujarat (and promoted export cash crop growth in their vicinity) only to draw down groundwater to catastrophic levels. While water managers in their silos do make decisions of highly specialized nature, and which by themselves are very necessary for the proper functioning of complex water delivery systems such as dams and waste water treatment plants, failure to appreciate or connect with activities 'outside the water box' (essentially externalities beyond their direct control) could spell disaster for activities within the box, and ultimately catch managers by unpleasant surprise.

Another UN report (FAO, 2014) argues that decisions on how to intervene made without cross-sectoral coordination and targeting only sector-specific optima risk increasing uncertainties across sectors and scales, altering the conditions under which they were designed: "In order to ensure the optimal management of trade-offs and the maximization of overall benefits, decision-making processes need to be reflective and take into account the dynamic nature of complex systems".

The question for nexus governance is: what goads silo managers operating within a complex system 
over the rest of which they have no control into that trans-sector reflection? This paper will argue that it can happen in one or more of three ways: charisma, disaster or mundane but democratic 'constructive engagement'.

What the UN WWAP as well as FAO reports are asking for - and the key word above is "reflective" - is replacing this silo-centered decision-making process by one where there is multi-directional, shared learning dialogue wherein interactions with the principal actors and the managers of a sector would sensitize them to the concerns of others that they in their own silos have been happily unconcerned with. As argued previously, there is value to specialization and managerial efficiency within silos. However, this is true only after major policy decisions are taken across a broad swathe of silos. What nexus considerations demand is cross-sectoral reflectiveness before major decisions are taken that affect water, energy or food, where intended and unintended quantified effects can be identified and discussed between all stakeholders.
Transcending conventional policy- and decision-making in silos and resorting to a nexus approach that builds synergies between sectors and conducts trade-offs that minimize loss while maximizing overall gain happens in the most fortuitous of cases with the charisma of leadership. For example, the historic megacases are those of a Meiji in Japan or a Peterthe-Great in Russia that forced warring Shoguns and Boyars out of their silo-ed fiefdoms and nexus-ed them for the larger national interests with a top-down royal edict. At a much more micro scale, in Nepal, community-led drinking water such as the township of Dhulikhel east of Kathmandu or the village of Phujel in Gorkha, present examples where water projects are developed with foresight for education and the setting up of a university (in the case of Dhulikhel, (Colopy, 2012) or vegetable gardening and domestic water supply in the case of Phujel). Ama Samuha ("mothers' group", a national NGO), community forestry groups in the district of Pyuthan or an agriculture cooperative (Marsyangdi Multipurpose

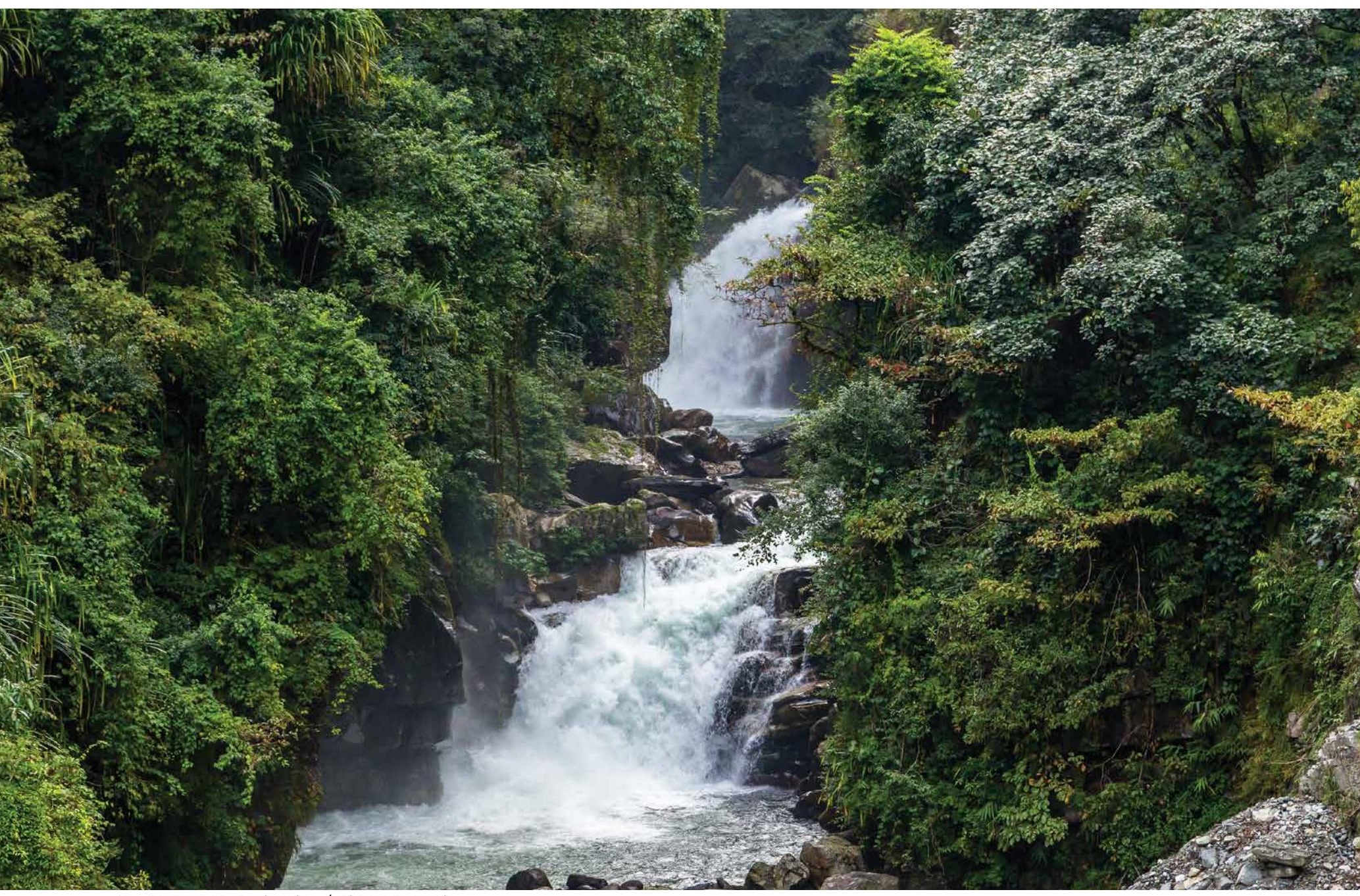

c) Evgeny Gorodetsky / Shutterstock 
Cooperative) in the highway crossroads town of Mugling have taken up community electricity and used it to develop lift irrigation, child care centers and other 'out of the box' non-silo ventures (Gyawali, 2014). These efforts have been led by charismatic leadership exploiting the minutest of policy openings.

The second 'best' situation arises with a major crisis/disaster in any one sector which then becomes a forensic moment prompting serious re-thinking within that and allied/linked sectors - and hence entry of new ideas and approaches, including the nexus approach. The 1993 Kulekhani disaster did prompt a push for decentralized power sector development as well as the opening for private sector participation in generation that previously the vertically integrated monopoly was averse to. The Arun-3 project that was then pushed by the World Bank and Nepal's Electricity Authority as "the only and best" option for Nepal (Gyawali, 1997) had to be abandoned because it was putting 'all the eggs in one basket'. In its aftermath, a slew of six other hydro projects were implemented in different parts of the country and under different institutional modalities that resulted in a third more electricity at half the cost and time.

Such fortuitous learning happens often enough in the aftermath of a crisis. Often that reflexive learning window closes quickly once media attention and hype shifts to other disasters or events as the April 2015 Nepal earthquake demonstrates, especially if there is not enough social activism to keep the issue alive. The highpowered rehabilitation commission set up under the prime minister's chairmanship did not meet even once in the subsequent six months, and its ordinance bill lapsed in the parliament. Seven months and a new government later, it still had not been set up.

A third situation, more probable but 'clumsy' in mundane times, happens within genuinely democratic polities where voices of dissent are not only given a seat at the policy table and heard but also responded to in a style of constructive engagement. As will be discussed below, where these aspects of nexus governance will be taken up, 'neat' solutions or technological choices are those imposed by a single social solidarity (market or government bureaucracy), often by silencing or ignoring voices of social and environmental critics. 'Clumsy' solutions are those where argumentative contestations occur, and each social solidarity is forced to reflect and absorb the concerns of the others, before a course (or courses) of action is decided upon. Clumsy because they take time, may unearth more problems to be solved thus 'delaying' progress; but also because the final compromise solution may look ungainly even if useful and more-orless acceptable to all contending stakeholders.

If leadership proves too elusively fortuitous and disasters too stochastic to plan for in bringing about a nexus approach in normal times, what is the more prosaic process to be followed? ${ }^{12}$ This synthesis paper, using the Theory of Plural Rationalities (more commonly referred to as Cultural Theory, see Thompson, 2008; Ney, 2009; Verweij and Thompson, 2006; Douglas, 1997; Maleki and Hendriks, 2014; and Gyawali, 2009, 2013), proposes that an approach that can transcend 'sectoral silos' -a nexus approach, can come about if the contradictory certitudes of all three of the principal active social solidarities (e.g. hierarchism, individualism and egalitarianism) are not only assured a voice at the policy table but also responded to. This helps to ensure synergistic and constructive engagement. The essence of social pluralism for a re-thought nexus governance framework can be described as follows below.

\section{'Integrated Social and Behavioural Science"}

Cultural Theory is a theory-in-making still contested even by its votaries as new applications are made and objections raised (Ellis and Thompson, 1997). It has some similarity to that propounded by upholders of 'multi-stakeholderism' (see Dore et al, 2010) but moves beyond to address the issue of power and its different types directly and to describe the necessary and sufficient characteristics of those stakeholders that wield different types

12 In line with the pluralistic thinking of this discussion paper, it is also argued that disasters are "unfinished business of development" that can function as forensic moments of change IF, and ONLY IF, the forces of change, i.e. socio-environmental movements (our third among the active social solidarities discussed below) are ready with their marshalled arguments and alternative pathways worked out and ready to jump in 
of powers ${ }^{13}$. It also does two things that make for strong contention: it tries to generalize understandings of human behavior from its rich base of social anthropological findings in exotic lands and climes, and to apply those generalizations to modern society and its problems.

\section{Figure 1. Constructive Engagement of Plural Social Solidarities}

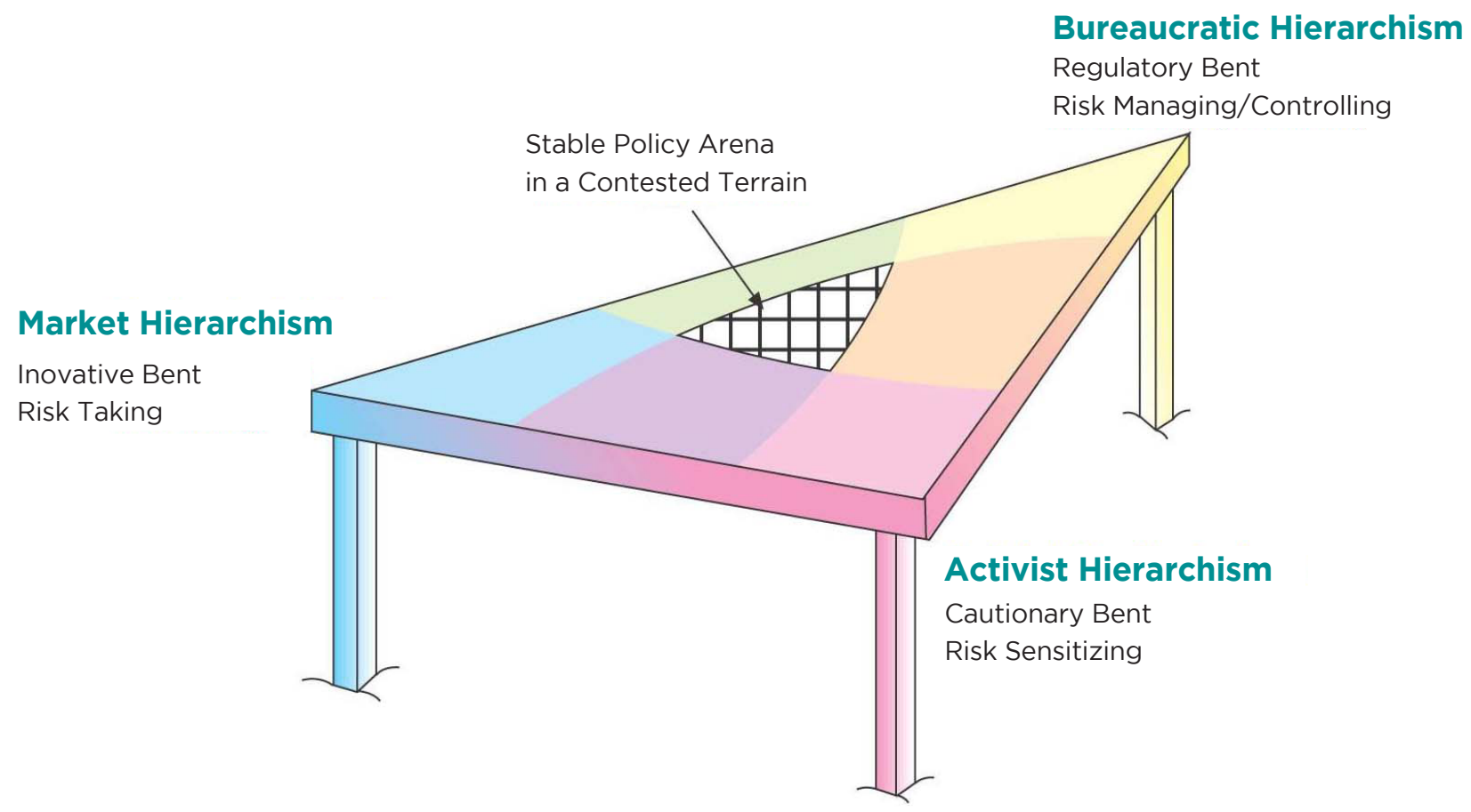

Source: D. Gyawali 2003. Rivers, Technology and Society, Zed Books, London

Its core framing is that two dimensions of sociality can adequately capture the variability of an individual's involvement in social life: transactions that are symmetrical or asymmetrical (nature of group affiliation and incorporation); and competition that is fettered and accountable or unfettered and unaccountable, in both cases the degree to which an individual's life is circumscribed by externally imposed loyalty and prescriptions. The greater the incorporation, the more is individual choice subject to group determination; and the more binding and extensive the scope of the prescriptions, the

13 Some scholars, including this author, have difficulties with the term 'stakeholder', a fairly sanitized term that ignores power relationships and seems to come from 'driving a stake and claiming surrounding land' in the American Wild West. India's former water resources secretary Ramaswamy lyer argued that he preferred to talk of 'stake-winners' and 'stake-losers'. less of life is open to individual negotiation. In one way, these two parameters are asking the fundamental questions of philosophy in human life: who am I (group affiliation)? And what should I do (the normative context of pre-ascribed rules)?
Regulatory Bent

Risk Managing/Controlling 
by noblesse oblige on the part of superiors (e.g. an English manor lord or an Indian Zamindar's fatherly patronage), examples being hydrocracies such as departments or ministries of water resources.

Strong group boundaries but weak prescriptions produce egalitarian social relations of socioenvironmental activists. Because these groups lack internal role differentiation, relations among group members are ambiguous and resolution of disputes is difficult. Because adherents are bound by group decisions but no one has the right to tell others what to do, slow and messy consensual decision-making is inevitable. Schisms are frequent and groups are held together often by alarmist causes (existing or invented) that highlight the threat from the outside.

Persons who are bound neither by group incorporation nor by pre-ordained roles inhabit the libertarian, social context of individualism. In such a social environment, all boundaries are provisional and subject to negotiation: what matters is the richness of network connections that are not structured. Freedom to negotiate is the guiding strategy and self-regulation the cherished belief (Adam Smith's [in]famous hidden hand of the free market), though such a way of life also requires an extraordinary, and perhaps paradoxical, degree of trust and mutual respect of rights, lacking which as is often the case, the state has to step in to enforce the law of contracts between these individualist players.

The most unenviable social location is the lowgroup, high-ascription environment of fatalism in which the conscript finds himself subject to binding prescriptions yet excluded from membership in the group for whose welfare decisions are made. The fatalized have little choice about how they spend their time, whom they associate with, what they wear or eat, or where they live and work. The fatalist endures the isolation of individualism without the freedom to organize his own network; he suffers the constraint of hierarchy without the support of a loyal group. They are the mass voters and consumers suffering in silence, strategized upon by the other three. The moment the fatalists actively organize a cognized strategy (and are not merely strategized upon) $\mathrm{s} / \mathrm{he}$ is no longer a fatalist. ${ }^{14}$ An absolute authoritarian hierarchy would not want to see any other solidarity (pesky social activist or freewheeling individualist) and would want everyone outside of their group boundary to behave as fatalist masses that do as they are told.

Each of these four types of social solidarities (or styles of organizing) is justified and sustained by an accompanying pattern of shared beliefs and values (or cultural biases and myths of nature that is common to them). This fourfold typology builds on previous research - particularly regarding the contested dualism of hierarchy and markets (Thompson and Gyawali, 2006) - but opens up relatively unexplored but important avenues of cultural expression, specifically fatalism and egalitarianism. Theory of Plural Rationalities bridges the old and new in organizational studies by opting for a three- or four-legged policy stool instead of the previous attempts at one- (pure authoritarianism) or two-legged (bureaucratic socialism and free market individualism, i.e. public-private partnership) ones. What is the hypothesis that this theory seeks to substantiate and what is the relation to WEF nexus?

The hypothesis is that the clumsy (and argumentative and noisy) arrangements that include all these different ways of active organizing - hierarchism, egalitarianism and individualism (fatalism does not strategize but is strategized upon by the other three, and the hermit at the center has withdrawn from all interaction voluntarily) - are the best because they prepare the system as a whole to better cope with surprises. This is something that rigid hierarchies (bureaucratic authoritarianism of rigid hydrocracies) or the libertarian markets (unbridled privatization) alone in an uncontested terrain consistently fail to do as they ignore or filter out other signals not conducive to their 'cosmologies'.

Systems where all the three active solidarities are present in a constructive engagement

14 New and on-going Cultural Theory research is challenging this notion of passive fatalism. Enrico (2014) argues that fatalism is more active than previously thought when it graduates into active cynicism, which is still reactive, unlike the other three social solidarities that have pro-active strategies that try to destabilize (or disorganize) the other two. 
are less prone to surprises (as opposed to one where there is no dialogue or where one has hegemonically drowned out the other two voices).
Theory of Plural Rationalities also argues that all these four solidarities have their own rationality, their own perception of risk (risk-taking individualism, risk-sensitizing

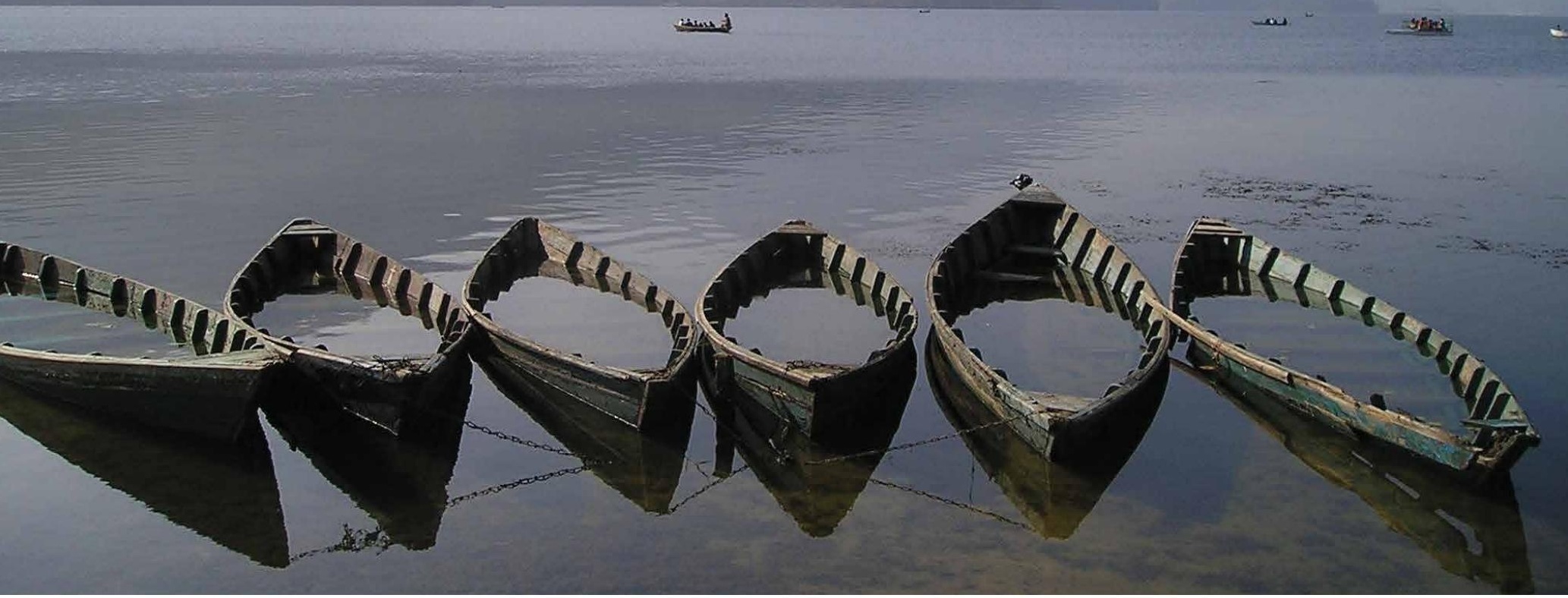

(c) PIXABAY

Hierarchism is guided by adherence to procedural rationality, where rules and regulations are the accepted path to follow. Individualism, unfettered by the need to uphold pre-defined rules or any established group loyalty, is guided by substantive rationality, which seeks richness of networks to further the bottom line benefits to contracting participants ("what in real substance is there in it for me"). Egalitarians, on the other hand, since they do not adhere to any pre-ascribed order that holds the group together, are engaged in critical rationality as it suits their alarmist strategy to uphold group boundedness. Fatalists (voters or consumers that have not been goaded into angry reaction), of course, can only have a coping rationality, wherein they would be the risk absorbers submitting to the risk strategies of the other three active solidarities. egalitarianism, risk-managing hierarchism and risk coping fatalism); their own view of what nature is (robust and taking care of itself, fragile and not to be interfered with, robust within limits but fragile if dealt with by violating environmental procedures defined by them, or capricious and unpredictable, respectively); and their own definition of 'what the problem is' that leads them to proffer different solutions and technology choices that makes sense in their own box but not necessarily in others.

These organizing styles also have very specific 'data filters'. This means that what is information to one could well be filtered out as noise by others, what is improbable 'statistical outlier' such as one extreme high flow data that could be ignored in dam design by hydrocracies 
because of high cost implications ${ }^{15}$ could be the very stuff of campaigns and public alarm by activist NGOs (see Gyawali, Allan et al, 2006). These filters, and the policy measures or actions they prompt to further their cosmology, can have distortive, de-nexused consequences if one organizing style has managed to acquire a hegemonic status, i.e either dominated by an unbridled market or dictatorial government bureaucracies or civic movements in the thrall of deaf fundamentalism.

Another implication of this 'integrated' approach to the social sciences - integrated because the very noisy and argumentative process of constructive engagement between them is what brings about the much hyped 'integration' and it cannot happen just through procedural decree from above or through the magic of the market's 'hidden hand' - is that one can tease out which particular social science each one of these active social solidarities has a proclivity towards. Hierarchism with its penchant for procedural rationality would prefer law and its coercive power; individualism that looks for substantive rationality of profits through better efficiency gravitates towards liberal market economics and its persuasive power; and socio-environmental activists prefer the moral high ground of ethics and anthropology of the grassroots, which allows them to deploy the only power they command - that of critique.

This broadening of the conceptual space also allows addressing the vexing problem of multi-, inter- and trans-disciplinarity ${ }^{16}$ to avoid the hegemony of one single discipline (in the case of water resources, civil engineering or market economics) dominating policy making.

15 This happened with the Bagmati irrigation barrage when the 1993 cloudburst struck and damaged the upstream Kulekhani as described earlier. It had been designed for a maximum flood flow of eight thousand cumecs even though one piece of uncomfortable data indicated it could be as high as twelve thousand, a bit of information that was rejected as a 'statistical outlier', i.e. noise. The actual flood was sixteen thousand, which resulted in the floodwaters overtopping the barrage, killing Chinese contractors and causing much more damage all around to life and property. There were no local activists formed around this national hydrocracy dominated scheme and hence no early alarm was raised of the risks involved in such hegemonic filtering out.

16 These fine distinctions between stages of interdisciplinarity depend upon whether only one hegemonic discipline 'feeds' the problem or is the feeding more plural, and whether solution theories are similarly uni- or pluri-disciplinary.
Thoren (2015) discusses sustainability science as one where problems arising in one discipline cross over and can only be solved by the help of another. He argues that melding disciplines would probably create more problems than it would solve and that the target should probably have to be "stabilizing problems and maintaining interdisciplinary contacts", i.e. maintaining constructive engagement. The old debate of defining and coping with interdisciplinarity, linkages between different sciences as well as the underlying different philosophies have thus got to be re-visited in the nexus debate.

It also has implications for new innovations to solve entrenched problems. Markets can be good at finding clever technical solutions, but they also introduce risks and redundancies. Although bureaucracies may be slow to change and often struggle with shifts in power dominance, bureaucratic hierarchism is well suited to find new managerial approaches to replace old ones so that new challenges can be better handled. As the opening to privatization and 'communitization' of the electricity sector in Nepal described above demonstrate, without their procedural innovations, good ideas from market players and civic activists will not be streamlined within a rapidly changing society. Without civic movements and their moral crusades, behavioral changes in a society cannot be brought about only by the coercive means of hierarchism or the persuasive blandishments of market individualism. ${ }^{17}$

For example, attempts to force market-innovated vaccines on a very religious society often fail without prior and significantly time- and resources-consuming community motivational work. New rural housing developed with bathtubs in cultures where bathing means letting the water wash away the dirt and not wallowed in, results in bathtubs being used as storage space for potatoes. Water shortages cannot be solved or maybe solved much more expensively than needed - if attempted only by focusing on a state

17 An imperfect example that comes to mind is the campaign against smoking by health activists, initial resistance by multinational tobacco companies, behavioural shaming by activists forcing smokers off common enclosed spaces, regulatory enforcement by governments, innovation by market players of e-cigarettes ... and the cycle continues. This dynamic cycle of market invention, activist protests, government intervention, followed by new inventions by the market in a repetitive cycle has been described in the case of the invention and popularization of the humble, two-wheel bicycle by Wiebe Bijker (1997). 
utility's piped water system expansion without encouraging conservation, recycling as well as clever private bottling systems. Proper nexus governance has thus to find a constructively engaged policy space for innovations of all three types - procedural, technical and behavioural as well as their social carriers, as the Theory of Plural Rationalities argues for.

\section{Whither Nexus Governance?}

This paper contends that, in mundane times unlike times of disaster or that led by charismatic leaders, the more horizontal and democratic process of constructive engagement between the three primary active social solidarities of market individualism, bureaucratic hierarchism and egalitarian activism would bring forth both the much-sought-for 'integration' as well as nexus thinking. This concept also addresses the shortcomings of previous efforts at integrating that suffered too much proceduralism and ignored the role of different types and amounts of power brought to bear by various protagonists. It further argued that 'what is the problem?' and 'what are the facts?' are questions that need to be preceded by asking 'whose facts?' and 'to what purpose were they collected?'.

In this sense, 'data democratization' is an inevitable requirement of such a plural policy terrain where those with different perceptions of 'what the problem is' would not only find information in the 'noise' discarded by other two, they would also strive to generate their own data to prove their hypothesis or version of truth. It is thus important to understand and reflect upon why integration did not occur with previous efforts such as with IWRM, why the nexus approach may similarly fail if the policy terrain remains monistic or dualistic, and why non-market and non-hierarchic values and approaches must also find space in governance and policy framing.

If we are to achieve a more nexus-like approach of trade-offs between WEF sectors, if we are to see a move from unstable monistic or even dualistic governance therein to one where varied voices of different social solidarities with differing perceptions of risk and technology choices co-exist, different definitions of 'what the problem is' must find a way to the policy table and must also be responded to by other voices. These different definitions of the problem will, it stands to reason, produce very different solutions and technical choices. The normal policy trend is either to pile up more bureaucratic rules and regulations on the one hand benefitting mostly only silo managers ('bureaucratic socialism'), or on the other a giving up of all regulation to market individualism, hoping that some quasi-divine 'hidden hand' does all that is required.

This monism and the only slightly more plural but still limited 'public-private partnership' are still deficient in that they ignore the critical voices of egalitarianism that often have the same function as canaries in a mine. Despite a few false starts and often excessive alarmism, they do have a critical function in preventing (or at least anticipating) unpleasant surprises. Such shocks happened with 'boil-over' in societies as diverse as those that saw the 'Arab Spring' in 2008 or the East Asian financial crises slightly earlier when it was happily hoped that a new post-Berlin Wall liberal order would let the global market and free trade anticipate and solve whatever problems may arise. In 1996 in Nepal the restored multiparty parliamentary democracy opted to champion unbridled privatization, as it was the developmental fad in the immediate post-Berlin Wall period. Early warnings that a poor and underdeveloped society would not be able to bear such social stress were ignored; and a rag-tag group of poorly equipped Maoists took to arms and quickly grew into a full-blown insurgency that caught everyone by surprise.

In the two Nepali examples cited above of Kulekhani and Melamchi, both were siloed projects led as flagship departmental 'hydrocratic' and hierarchist ventures, the former a hydropower project and the latter a water supply project. Voices of critique against Kulekhani - that it was too expensive, that there was better use of that reservoir's water to be used instead to quench Kathmandu's thirst were drowned out by the hegemons, often with the state's coercive threats that the critics were 'anti-national' and 'anti-development'. No one represented (at the national level) the voices of those displaced, and what egalitarian voice 
existed against injustice was too far below in the poor villages in the marginalized hinterlands to be heard in the triumphalist developmental din of the capital. These voices went underground, so to speak, and resurfaced via the informal economy as fishing communities that were able to articulate their version of development and the economic choices possible for them only after multiparty democracy was restored.

In the case of Melamchi, we have the case of a hierarchic and hegemonic hydrocracy "managing" urban water shortage in partnership with a development bank promoting private financial and contractor/
The NGOs advocating a 'bigger Melamchi, multipurpose Melamchi' have their vision set at the national and international level. They are not really championing the egalitarian case at the local level where diversion of water from the smaller tributaries to feed a larger (and nationally far more beneficial) Melamchi would have adverse local consequences to farmers, their farms as well as water mills. Championing the case for smaller scale development suited to the needs of the poor farmers is what the Thai NGOs are doing as highlighted above again a case of context and levels. This aspect helps bolster the argument made above that the closer decision-making is to the lowest

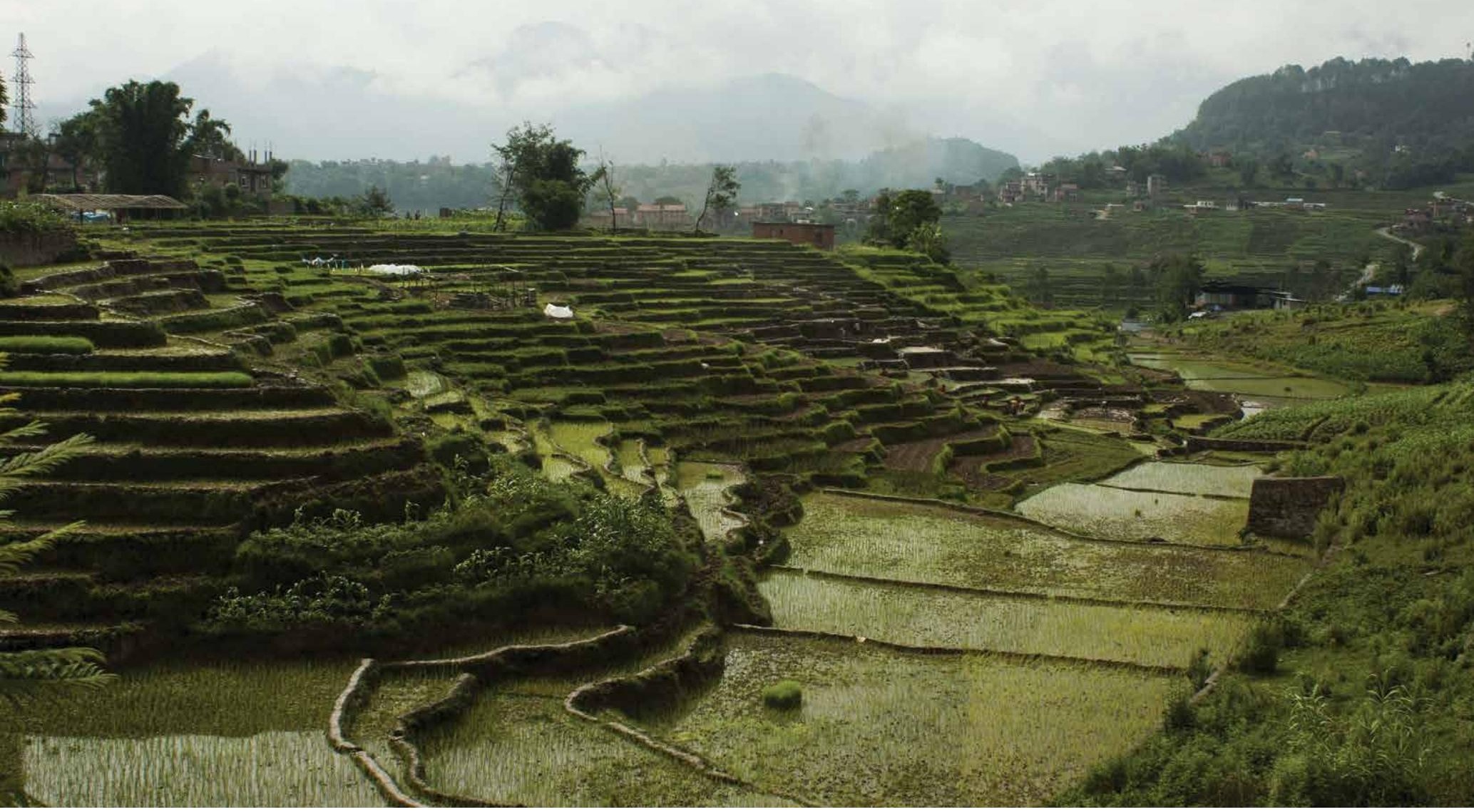

(c) PIXABAY

supplier interests of market individualism. Missing at the policy table is the voice of $\mathrm{NGO}$ activist egalitarianism that sees the entire project as designed and executed wastefully with unfair high cost consequences to the urban water and electricity consumers. This case also serves to highlight the role of levels or scales. unit of governance (i.e. the farming family and village councils), the better the chance of a genuine and appropriate nexus approach to develop. It would then allow the higher bodies to function as adjudicating oversight bodies and not to champion causes and technologies of a silo-ed nature. 
The contention of the Theory of Plural Rationalities is that, when integration or, by way of example, the water, food, and energy nexus are approached as too much of a hierarchic regulatory issue governed by rigid rules and procedures, it is not constructive but destructive and bound to eventually fail if the concerns of free-wheeling market individualism or justice-seeking activist egalitarianism are also not met.

In Nepal's case of hydropower development, projects that are conceived and developed at the local level with some form of community ownership seem not only to be mostly conflict free (or at least with the conflict locally resolved) even during the worst period of Maoist insurgency (e.g. 4MW Piluwa Khola in the Arun basin despite suffering bombing by the Maoists), but also capable of introducing nexus thinking, as with the 5MW Andhi Khola hydroelectric project that introduced irrigation from its tailrace.

Conversely, the further decision-making moves away from village councils to municipalities to district headquarters to national and international agencies decisions can become more entrenched and hegemonic as the process becomes expertise-dominated silofication that ignores such nexus opportunities (as demonstrated by the Kulekhani case). Such a move towards specialization and inflexible procedures needs to be counterbalanced by oversight bodies that cross-cut across departmental boundaries.

A key question is how such bodies (i.e. national planning or parliamentary commissions, transdepartmental committees chaired by the prime minister, even courts with judicial activism etc.) are constituted and mandated and then, after they are put into place, whether they are open to seeing and promoting innovations needed for a nexus approach to solve intertwined problems. In Nepal's case, vested political interests have colluded to promote large, siloed water projects by ignoring or hamstringing such oversight bodies. In countries where they have been properly empowered and are capable of long-term strategic thinking, they have managed to bring about laterally thought out and nexused benefits. The example that comes to mind is Singapore's efficient and multi-hued water management that relies not only on import but also recycling and water harvesting, where its Changi international airport is one large water harvesting structure. A similar use of the airfield takes place on Majuro atoll in the Marshall Islands (Pangare et al., 2012).

And to understand where such innovations will come from in different socio-environmental contexts, the understanding of Cultural Theory is that they are needed in all three of the different styles of organizing and at each level of organizing from the grassroots to the global, as per the inherent strengths of each. These three styles of organizing deploy different types of power, are disciplined by them and seek to discipline the others (indeed, policy has been defined as a "formula for the use of power"):

- government bureaucracies apply coercive power ("the disciplinary executive, follow the law or go to jail");

- markets deploy persuasive power ("buy this product"); and

- civic movements specialize in moral power or pressure ("you are being bad to society, environment, the poor... when you...").

It is with these tools that each of the different styles of organizing has to engage with the others in a nexus approach and to concentrate at points where they inevitably intersect. If local context matters, then a typology of contexts is needed which is what Cultural Theory provides with its 'impossibility' theorem that there are only these limited number of social solidarities at all levels and its 'requisite variety' condition that if one solidarity is there, the others will be there too, but possibly even underground (Thompson, 2008). Only a constructive engagement between all of them will provide for policy stability as well as a chance for the broad thinking of the nexus approach.

This paper points out that distortions do occur in each of the social solidarities, perhaps much more often than we normally think - which is the reason for the argument made above that the nexus approach must move away from the singular 'best practices' approach of development to one of a problem solving, review 
and evaluation approach to ensure lessons can be learned. Cultural Theory would argue that, in a dynamic and constantly changing world, it is when a social solidarity loses its Dharma ${ }^{18}$ that only a constructively engaged level and sufficiently pluralized playing field would be able to restore that Dharma (Gyawali, 2004). can equally help with transport, storage and waste disposal. Energy can be produced from many sources and in different locales: new water cannot be manufactured except in a lab and one has to live within its limits, re-cycling and re-using it where possible. Energy - especially non-renewable - can

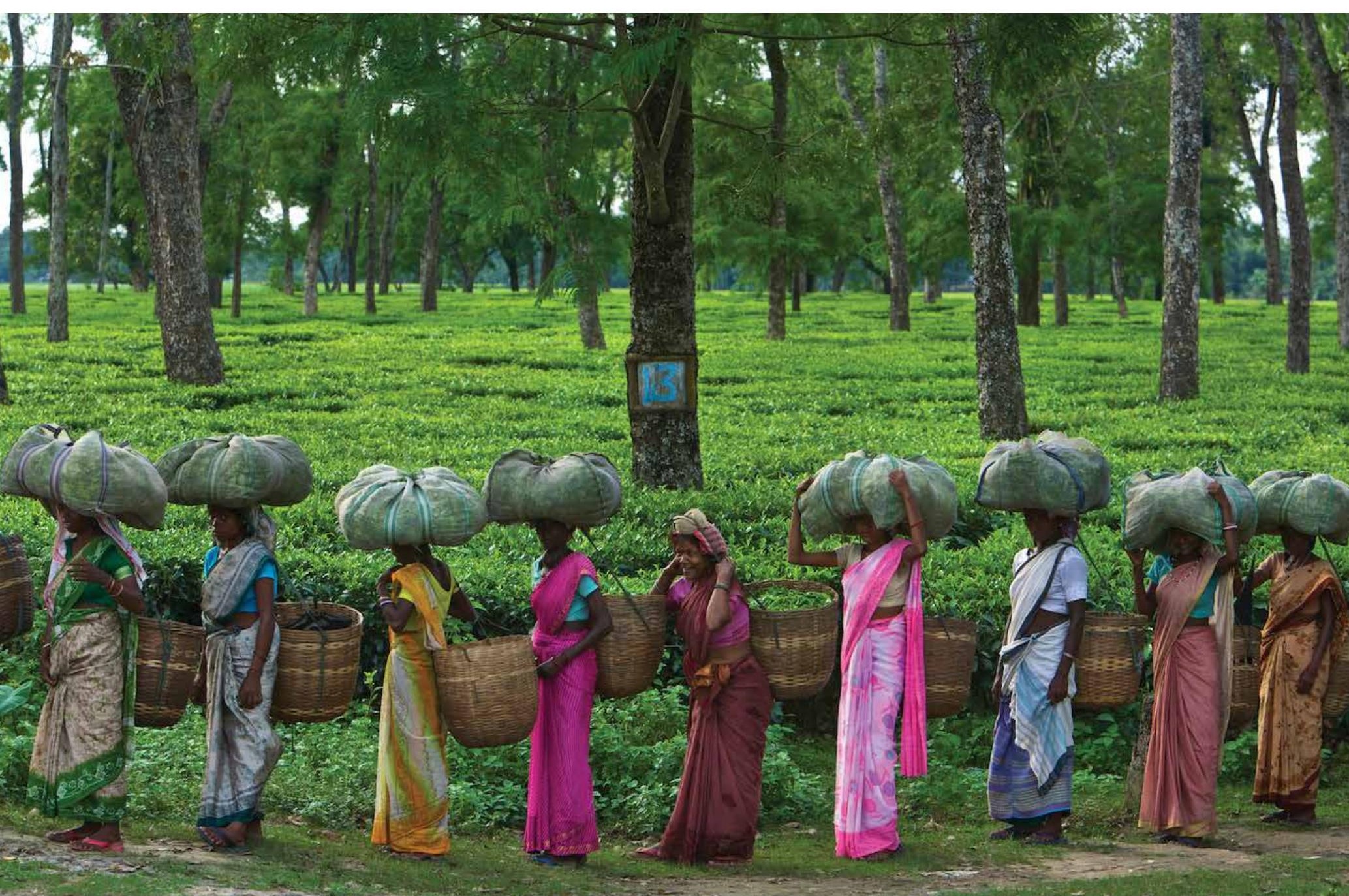

IUCN Photo Library / ( Steve Winter

There are fundamental physical attributes and differences between the three WEF sectors that must be taken into account when considering each other's limits, synergies and entwined predicaments. A nexus approach understood from a Cultural Theory perspective helps us do that, especially when we look at different interstices where nexus thinking

18 The Sanskrit term Dharma is often wrongly translated as 'religion' when it really means 'appropriate way of life'. The Dharma of activist egalitarianism is to critique and warn of risks, that of the market individualism to take risks and innovate, and that of state hierarchism to assure regulation and fair redistribution. It is when they deviate from that and do what the Dharma of other solidarities is that we have a case of Dharma gone bad. be mined and the institutional requirements for it can be handled as a security issue: just send in your army, secure the site and mine away. Water (including sustainably extracted groundwater as well as food) needs to be primarily harvested. They have often been mined by over-extraction including that of soil fertility, with disastrous consequences seen around the world. It is only at their specialized ends that food and water need silo-ed expert processing.

While it is true that water-energy-food are nexused at their respective production stage, each sector only considers the other as mere 
input. Little thought is given unless there is a shortage in the supply chain. At the production stage, they also have well-established, even if narrow-focused and rigidly set engineering procedures to deal with such input issues. There are, however, three other major points of intersection where the intrinsic nexus is often ignored or downplayed and where significant progress in nexus governance could be made if brought to salience. For the governance of the nexus to be further debated, developed and innovations sought consideration should also be given to: storage as well as transport and waste disposal of all three items of water, energy and food.

All three items - water, energy and food - have to be stored and transported from production to consumption to waste disposal at a variety of levels and by a variety of technologies. And it is at these points of storage, transportation and waste disposal that different sectors have to engage, with issues such as food miles, virtual water, failure of economics and often policy fed by narrow business economics to deal with 'bads' (Thompson, 1979). Moreover, there are two governance indicators at these intersection points where engagement has to be sought between the three active social solidarities:

- considerations of efficiency that markets and governments readily understand but which raise equity questions; and,

- considerations of each other's footprints that need reflecting over - which civic movements and governments understand but markets do not readily do so unless coerced by government regulatory and tax measures.

For example, it has been estimated ${ }^{19}$ that $15-50 \%$ of food crops are lost between production and the market globally (and in developing countries as high as $65 \%$ ). This translates into the wastage of almost a quarter of all freshwater, crop area and fertilizer currently used for food production. Moreover, while much of the food wasted in developed countries is at the household level, in developing countries it is at the level of field and transportation.

Based on the case studies presented in this paper and the arguments made for governance through constructive engagement between the three styles of active organizing - bureaucratic hierarchism, market individualism and activist egalitarianism - a new WEF nexus governance approach might be framed around the interstices of storage, transport and waste disposal. And the guiding philosophy might be considerations of efficiency and mutual water and energy footprints as areas where market individualism has to bring forth technological, bureaucratic hierarchism has to bring about regulatory and activist egalitarianism has promote behavioural and value innovations respectively. Critical is to avoid policy capture by the loudest hegemon and the drowning out of other voices that can be detrimental across sectors.

Markets reward efficiency which has long been promoted as the primary governance indicator; but the rules for those rewards have to be broadened by hierarchic agencies to accommodate voices of egalitarianism that champion the non-efficient (in purely market terms) benefits of social justice. Water footprints or energy footprints of food as well as other consumer products is another governance indicator that has found favour among the civic egalitarian voices that has a strong ethical ring to it. Binding common objectives across institutions and down through sectors via appropriate indicators require that activist egalitarianism needs to move beyond critique and to support multi-stakeholder platforms for dialogue in a way that allows for uncomfortable knowledge to find clumsy solutions. Government agencies of course have to assure that such policy platforms are not only in place but are also both inclusive and responsive. Thus may we expect a nexus approach emerge without having to wait for fortuitous leadership or a major disaster.

19 In a presentation made by Antonio Acedo Jr. of the World Vegetable Center, ICRISAT Campus, Hyderabad, Telangana, India at the AIT nexus workshop in Bangkok on 22-23 January 2013: Water Energy Food Nexus - Critical Role of Food Loss Reduction and AVRDC's Initiatives in the Mekong Region and Asia. 


\section{References}

Allan, T. (J. A.) (2003). IWRM/IWRAM: a new sanctioned discourse? SOAS/London: Occasional Paper 50 .

Allouche, J.; Middleton C. and Gyawali, D. 2015. Technical veil, hidden politics: Interrogating the power linkages behind the nexus. Water Alternatives 8(1): 610-626. Downloadable at: http://www.wateralternatives.org/index.php/alldoc/articles/vol8/v8issue1/277-a8-1-1/file

Allouche, J., Middleton, C., and Gyawali, D. (2014). Nexus Nirvana or Nexus Nullity? A dynamic approach to security and sustainability in the water-energy-food nexus. STEPS Working Paper 63, Brighton: STEPS Center. Downloadable at: http://steps-centre.org/wp-content/uploads/Water-and-theNexus.pdf

Beck, B. Thompson, M., Ney, S., Gyawali, D. and Jeffrey, P. (2011). On Governance for Re-engineering City Infrastructure. Institute of Civil Engineers: Engineering Sustainability Volume 164 Issue ES2

Bijker, W. E. (1997). Of Bicycles, Bakelites and Bulbs: Towards a Theory of Socio-Technical Change. Cambridge, MA: MIT Press

Biswas, A. K. (2008). Integrated Water Resources Management: Is It Working? Water Resources Development: Vol. 24, No. 1, 5-22, March 2008

Colopy, C. (2012). Dirty, Sacred Rivers: confronting South Asia's water crisis. London: Oxford University Press.

Dore, J., Robinson, J. and Smith, M. (eds) (2010). Negotiate - Reaching Agreements over Water. Gland, Switzerland: IUCN

Douglas, M. (1987). How Institutions Think. London: Routledge and Keegan Paul.

Ellis, Richard and Michael Thompson (eds) (1997). Culture Matters: Essays in Honour of Aaron Wildavsky, Boulder, Colorado: Westview Press.

Enrico, Claudio Pardo (2014). Discursive Constructions of Private Military Security, PhD Thesis (Bremen: Bremen International Graduate School for the Social Sciences, (in progress), chapter 4.)

FAO (Food and Agriculture Organization of the United Nations, 2014). The Water-Energy-Food Nexus: A new approach in support of food security and sustainable agriculture. Rome.

Gyawali, D. (2014). How to Energize Women - the Nepali Response. Bulletin of Atomic Scientists, vol 70(2) 9-12. The full roundtable debate can be accessed at the website: http://www.thebulletin.org/ expanding-energy-access-improving-womens-lives

Gyawali, D. (2013) Reflecting on the Chasm between Water Punditry and Water Politics, in Water Alternatives 6(2): 177-194 http://www.water-alternatives.org/index.php?option=com content\&task=view\&id=45\&ltemid=1

Gyawali, D. (2009) Pluralized Water Policy Terrain = Sustainability and Integration, viewpoint in eJournal www.sawasjournal.org Hyderabad: South Asian Water Studies (SAWAS). 
Gyawali, D., J.A. Allan et al., 2006. EU-INCO water research from FP4 to FP6 (1994-2006) - a critical review. Luxembourg, Office for Official Publications of the European Communities, $86 \mathrm{p}$.

Gyawali, D. (2004). Foreign Aid, Governance and Corruption. Chapter in S. Sharma, J. Koponen et al (eds) Aid Under Stress: Rural Water Supply, Forestry \& Finnish Aid in Nepal. Kathmandu: Himal Books for University of Helsinki and Interdisciplinary Analysts, Kathmandu.

Gyawali, D. and Dixit, A. (1999). Fractured Institutions and Physical Interdependence: Challenges to Local Water Management in the Tinau River Basin, Nepal. Chapter in Moench, M., Caspari, E. and Dixit, A. (eds.) Rethinking the Mosaic - Investigations into Local Water Management. Kathmandu: Nepal Water Conservation Foundation, Kathmandu and Institute for Social and Environmental Transition, Boulder, Colorado.

Gyawali, D. (1997). Foreign Aid and the Erosion of Local Insititutions: An Autopsy of Arun-3 from Inception to Abortion. Chapter in C. Thomas \& P. Wilkins (eds.) Globalization and the South; in International Political Economy Series (Series editor Timothy Shaw/Dalhousie University), Macmillan London and St. Martin's Press New York.

Gyawali, D. (1996). Economic Security in a Predominantly Informal World: South Asian Realities and Global Elation With Liberalization. Chapter in Iftekharuzzaman (ed.) Regional Economic Trends and South Asian Security; published by the Regional Center for Strategic Studies, Colombo and Manohar Publishers and Distributors, New Delhi.

ICIMOD. (2015). Reviving the Drying Springs: Reinforcing Social Development and Economic Growth in the Midhills of Nepal. Issues Brief, February. International Center for Integrated Mountain Development (ICIMOD), Kathmandu, Nepal.

Jantzen, D., B. Pandey, R.S. Shrestha and O. Hoftun. (2008 October), Multi Purpose Melamchi Project, Concept Level Technical Report, Kathmandu, Nepal: UMN Himal Hydro Volunteer Group and Sanima Hydro.

Jeffrey, P. and Gearey, M. (2006) Integrated water resources management: lost on the road from ambition to realisation? IWA Publishing: Water Science \& Technology Vol 53 No 1 pp 1-8 Q

Kumar, D. M., Bassi, N., Narayanamoorthy, A. and Sivamohan M. V. K (eds) (2014). The Water, Energy and Food Security Nexus: Lessons from India for Development. London: Routledge Earthscan.

Maleki, A. and Hendriks, F. (2014). Grid, Group, and Grade: Challenges in Operationalizing Cultural Theory for Cross-National Research. Sage Online - http://ccr.sagepub.com/content/ early/2014/10/23/1069397114555843

Mehta, L. (ed) (2010). The Limits to Scarcity: Contesting the politics of allocation. London: Earthscan.

Middleton, C and Allen, S. (2014). The (re)discovery of "the Nexus": Political economies and dynamic sustainabilities of water, energy and food in Southeast Asia. Bangkok: Chulalongkorn University

Middleton, C.; Allouche, J.; Gyawali, D. and Allen, S. 2015. Where's the (environmental) justice? The rise and implications of the water-energy-food nexus in Southeast Asia. Water Alternatives 8(1): 627-654. Downloadable at: http://www.water-alternatives.org/index.php/alldoc/articles/vol8/ v8issue1/269-a8-1-2/file

Moench, M. et al (2003). Fluid Mosaic: Water Governance in the Context of Variability, Uncertainty and Change (A synthesis paper). Kathmandu: Nepal Water Conservation Foundation (NWCF) and Institute for Social and Environmental Transition (ISET-Boulder). 
Molle, F. 2008. Nirvana concepts, narratives and policy models: Insight from the water sector. Water Alternatives 1(1): 131-156).

Ney, S. (2009). Resolving Messy Policy Problems: handling conflict in environmental, transport, health and ageing policy. London: Earthscan.

Pangare, G., Das, B., Lincklaen Arriens, W., and Makin, I. (2012). WaterWealth? Investing in Basin Management in Asia and the Pacific. New Delhi, India: Academic Foundation. 92 pp.

Smith, M., and Jønch Clausen, T. (2015). Integrated Water Resource Management: A New Way Forward. A Discussion Paper of the World Water Council Task Force on IWRM.

Thompson, M. (2008). Organising and Disorganising: A Dynamic and Non-Linear Theory of Institutional Emergence and Its Implications. UK Axminster: Triarchy Press

Thompson, M. and Gyawali, D. (2006). Uncertainty Revisited or the Triumph of Hype over Experience. New introduction to Thomson, M., Warburton, M. and Hatley, T. (1986: London, Milton Ash Editions, an imprint of Ethnographic) Uncertainty on a Himalayan Scale. Kathmandu: Himal Books with James Martin Institute for Science and Civilization, Oxford University and the International Institute for Applied Systems Analysis, Vienna.

Thompson, M. (1979). Rubbish Theory: the creation and destruction of value. Oxford: Oxford University Press.

Thoren, H. (2015). The Hammer and the Nail: Interdisciplinarity and Problem Solving in Sustainability Science. PhD dissertation. Department of Philosophy, Lund University, Sweden.

Verweij M, and Thompson M. (eds) (2006). Clumsy Solutions for a Complex World, Basingstoke UK: Palgrave/Macmillan

Villamayor-Tomas, S.; Grundmann, P.; Epstein, G.; Evans, T. and Kimmich, C. 2015. The water-energy-food security nexus through the lenses of the value chain and the Institutional Analysis and Development frameworks. Water Alternatives 8(1): 735-755

WWAP (2009). United Nations Third World Water Assessment Report. Paris: UNESCO. 


\section{What is the Nexus?}

Water uses energy, energy uses water, agriculture needs both and modern society needs all three; and they all rely on infrastructure to manage water. In this way, land, water and energy systems are inter-connected and have become increasingly more complex and dependent on one another. As a result, disturbance and change in one system can destabilise the others. For example, recent extremes of droughts and flood have forced an evaluation of how water infrastructure impacts other sectors - highlighting the need for a 'nexus based' multi-disciplinary, cross-sectoral approach to look for 'win-win' solutions while balancing environmental, social and economic issues. As world populations continue to grow, they will need to be serviced with water, energy and food against a backdrop of climate change.

The nexus - a series of connections, or the focal point of connections. The Nexus Dialogue is designed to speak across sectors to allow for a two way exchange or flow of information and perspectives. Through this process joint learning can be encouraged, perspectives understood, and joint solutions identified.

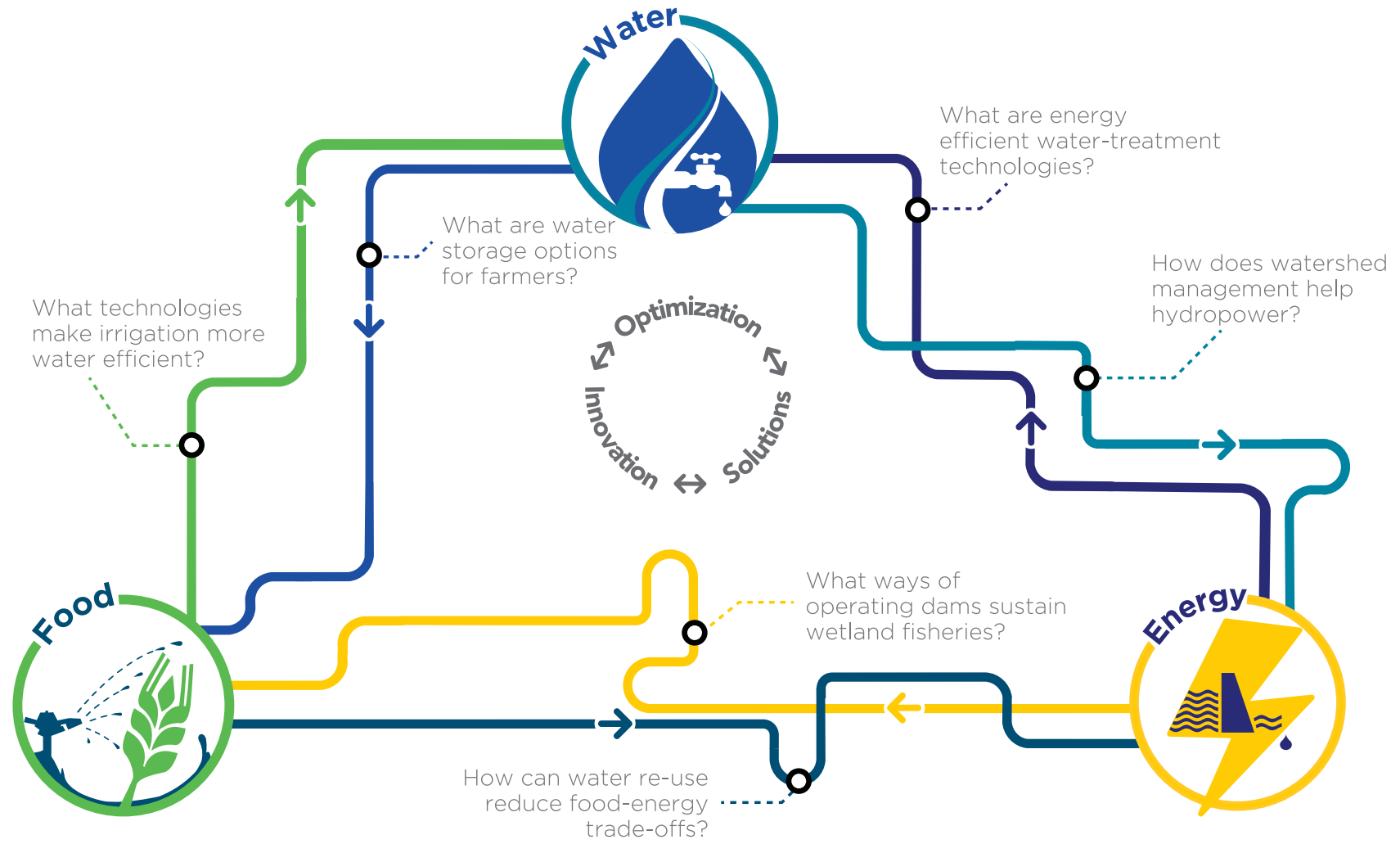

(c) IUCN WATER, Infographic design: Carolyne Daniel, Zoï Environment Network 
IUCN and IWA would like to acknowledge the following people/institutions for their valuable contributions to the Nexus Dialogue:

Participants of the Anchor Workshops in Nairobi, Bogotá, Bangkok, and Istanbul. Participants at the Beijing Symposium, Mr. Zheng Rugang, Secretary General and Coordinator of GWP China; Michele Ferenz, Hope Schaitkin and James Creighton from the EastWest Institute; Salmah Zakaria and Hongpen Liu from UNESCAP in Bangkok; as well as interactions and discussions with participants at various events (in Berlin, Paris, Stockholm, Chapel Hill North Carolina, Washington D.C, London, Nairobi, Amsterdam, Mexico City, Lisbon, and Geneva).

All Reference Group Members and Key Contributors to the Dialogue, in particular Jeremy Bird from IWMI, and Dipak Gyawali from the Nepal Academy of Science and Technology.

All Synthesis Paper Authors and Reviewers, as well as the UNECE Secretariat in Geneva; CEPAL in Santiago, Chile; Ulrike Pokorski da Cunha, Pierre Guillebert, Gerhard Rappold, Philipp Peters, and Detlef Klein from GIZ; Helen Bellfield and Niki Mardas from The Global Canopy Programme, Oxford; Chuck Chaitovitz from the US Water Partnership; H.E. Ambassador Lisa Svensson of Sweden; Louise Gallagher from the Luc Hoffman Institute and Stuart Orr from WWF International; Christian Bréthaut from the University of Geneva; Jordan Macknick of the U.S. National Renewable Energy Laboratory; Reagan Waskom from Colorado State University; Jean Comby, Laurent Bellet and Emmanuel Branche from Electricité de France; Emilio Lèbre La Rovere and Fernanda Tayt-Sohn from the Federal University of Rio de Janeiro; Franz Rojas Ortuste; and Damian Crilly from the U.K. Environment Agency.

\section{About IUCN}

IUCN, International Union for Conservation of Nature, helps the world find pragmatic solutions to our most pressing environment and development challenges.

IUCN's work focuses on valuing and conserving nature, ensuring effective and equitable governance of its use, and deploying nature-based solutions to global challenges in climate, food and development. IUCN supports scientific research, manages field projects all over the world, and brings governments, NGOs, the UN and companies together to develop policy, laws and best practice.

www.iucn.org

\section{About IWA}

The International Water Association is the organisation that brings together science and practice of water management in order to reach a world in which water is wisely managed to satisfy the needs of human activities and ecosystems in an equitable and sustainable way.

The IWA is a global knowledge hub and international network for water professionals and anyone concerned about the future of water. We bring together know-how and expertise to instigate groundbreaking solutions.

www.iwa-network.org

For more information on the Nexus Dialogue, please visit www.waternexussolution.org 


\section{IUCN IM \\ the international
water association}

Visit the Nexus Dialogue website:

www.waternexussolutions.org

Join us on Twitter $@$ WaterNexus and Facebook

Take part in online discussions with experts

Contact us: info@waternexussolutions.org

\section{CONTACT DETAILS}

\section{Dr Mark Smith}

Director IUCN Global

Water Programme

Rue Mauverney 28

1196 Gland

Switzerland

www.iucn.org/water

Scan me

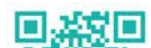

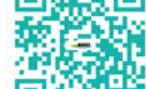

\section{Dr Ger Bergkamp}

Executive Director IWA

Koningin Julianaplein 2

2595 AA Den Haag

The Netherlands

www.iwahq.org
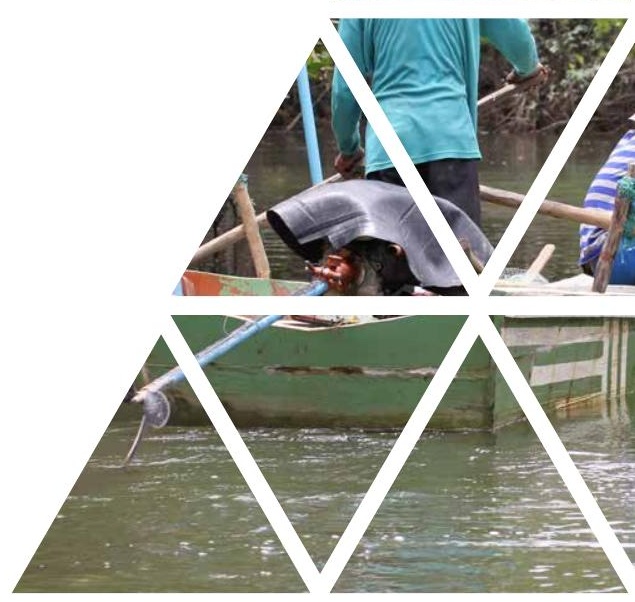

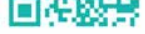

